\title{
Highly Efficient Catalysts for the Formation of Tetrasubstituted Olefins via Ring-Closing Metathesis
}

\author{
Ian C. Stewart ${ }^{1}$, Thay $\mathrm{Ung}^{2}$, Alexandre A. Pletnev ${ }^{2}$, Jacob M. Berlin ${ }^{1}$, Robert H. Grubbs ${ }^{1}$, Yann \\ Schrodi $*, 2$ \\ The Arnold and Mabel Beckman Laboratory of Chemical Synthesis, Division of Chemistry and Chemical \\ Engineering, California Institute of Technology, Pasadena, California 91125, and Materia Inc., Pasadena, \\ California 91107
}

\section{Supporting Information}

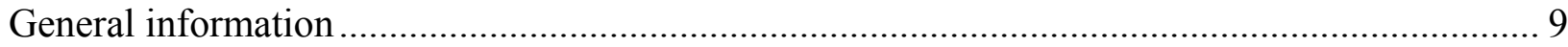

General procedure for the preparation of $N, N^{\prime}$-Diaryl oxamides …………………………….... 10

General procedure for the preparation of $N, N^{\prime}$-Diarylethylenediamine hydrochloride.................. 10

General procedure for the preparation of imidazolinium chloride ............................................ 10

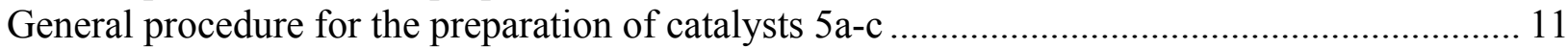

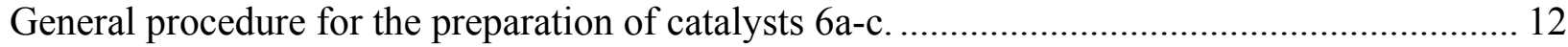

General procedure for the RCM of 7 (monitored by GC) ........................................................ 14

General procedure for activity plots of ring-closing metathesis................................................... 18

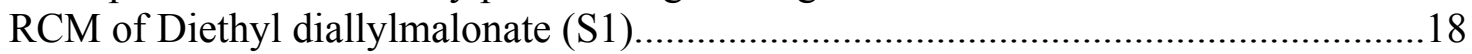

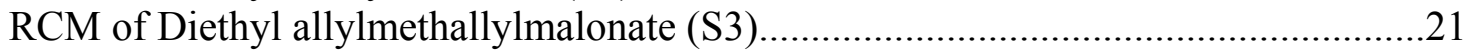

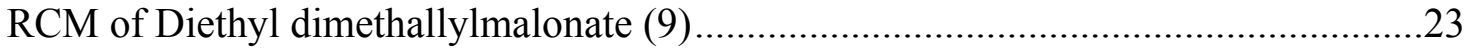

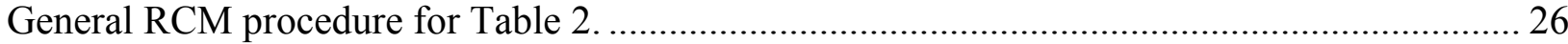

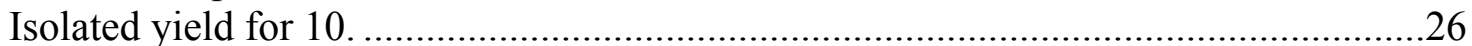

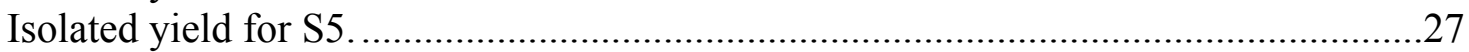

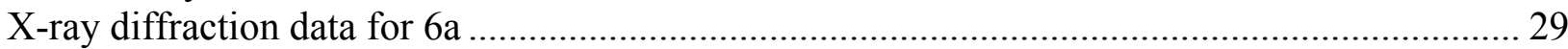

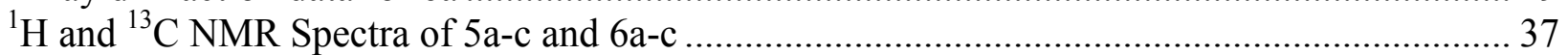

${ }^{1}$ California Institute of Technology

${ }^{2}$ Materia, Inc. 

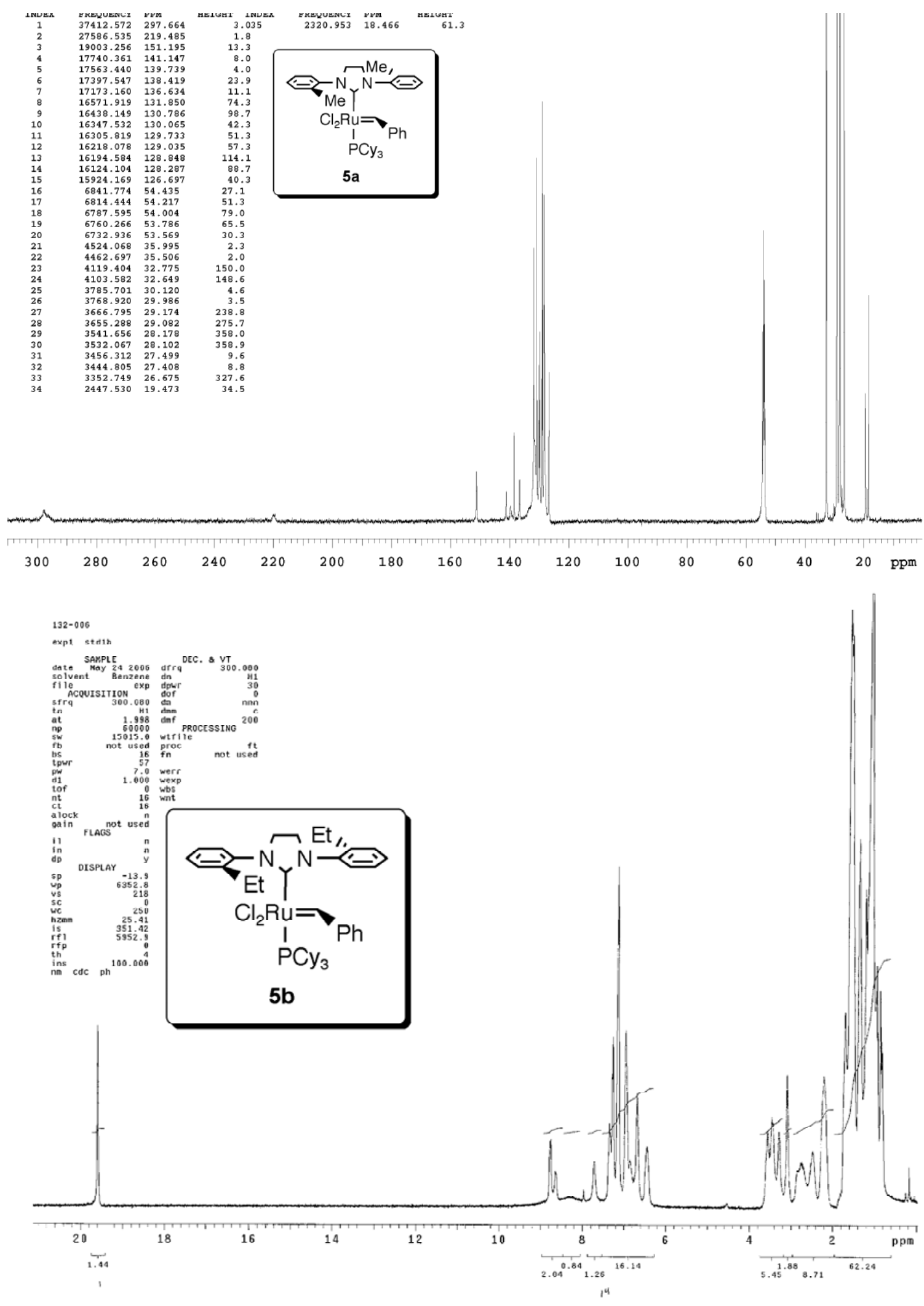

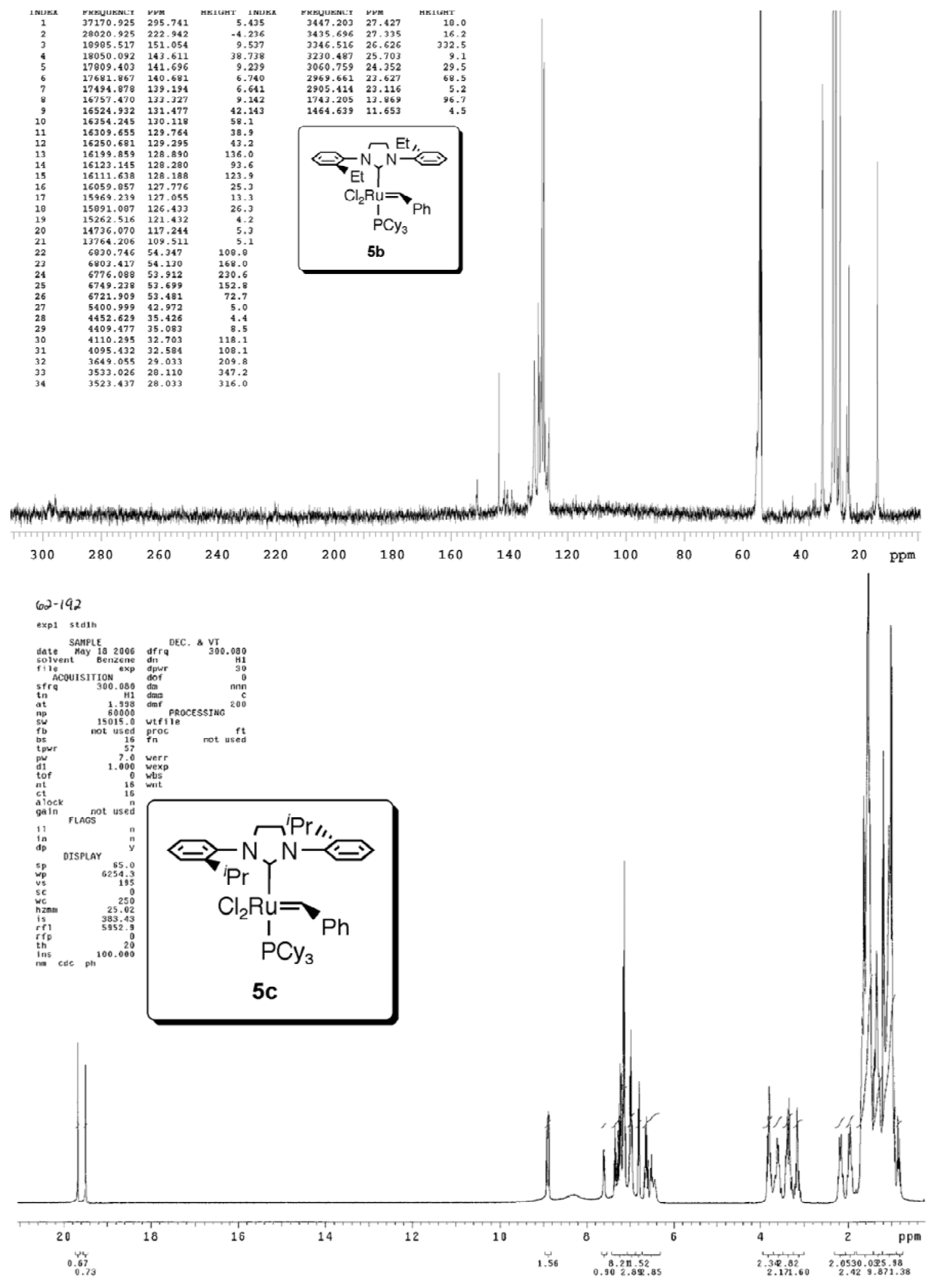

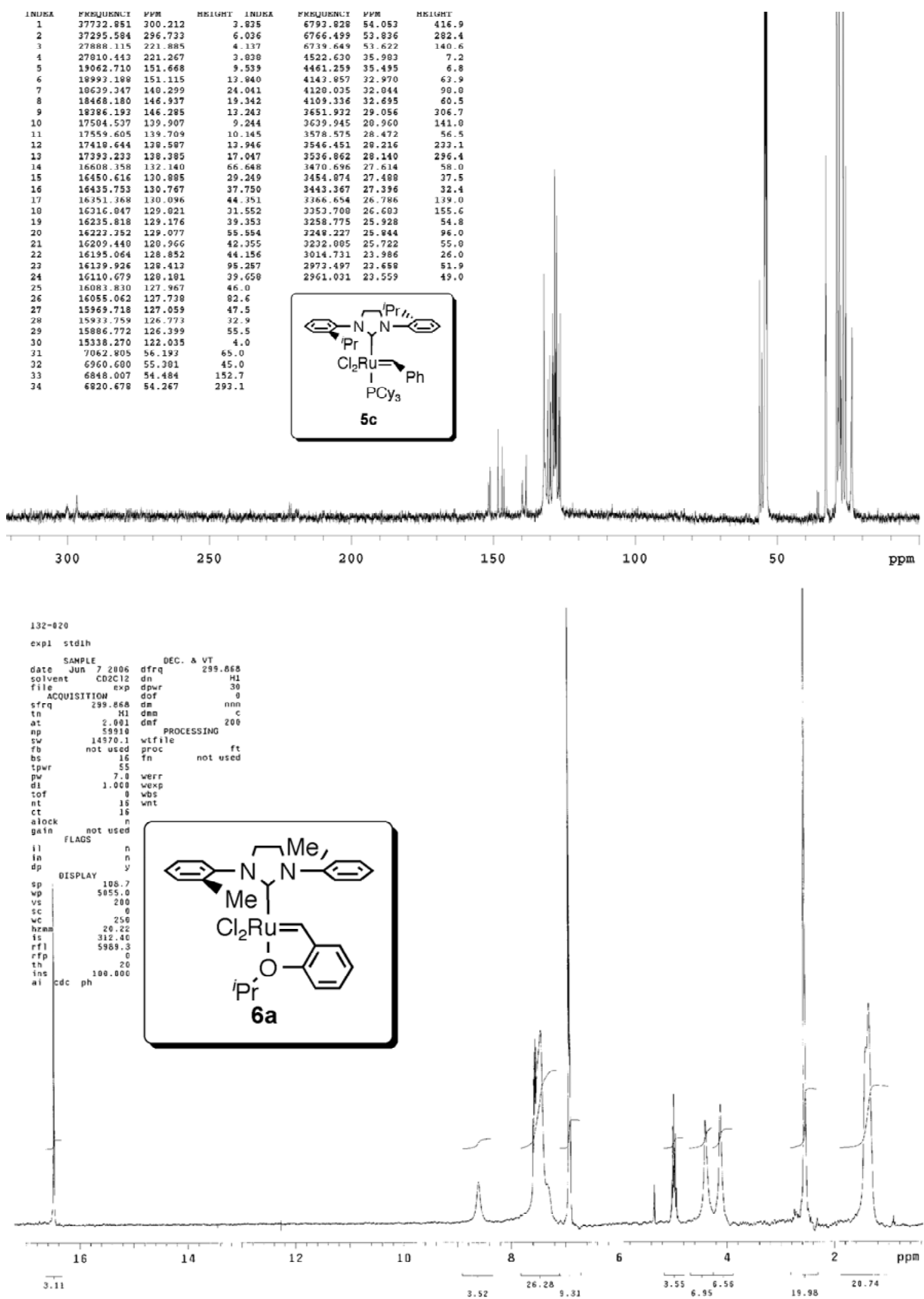

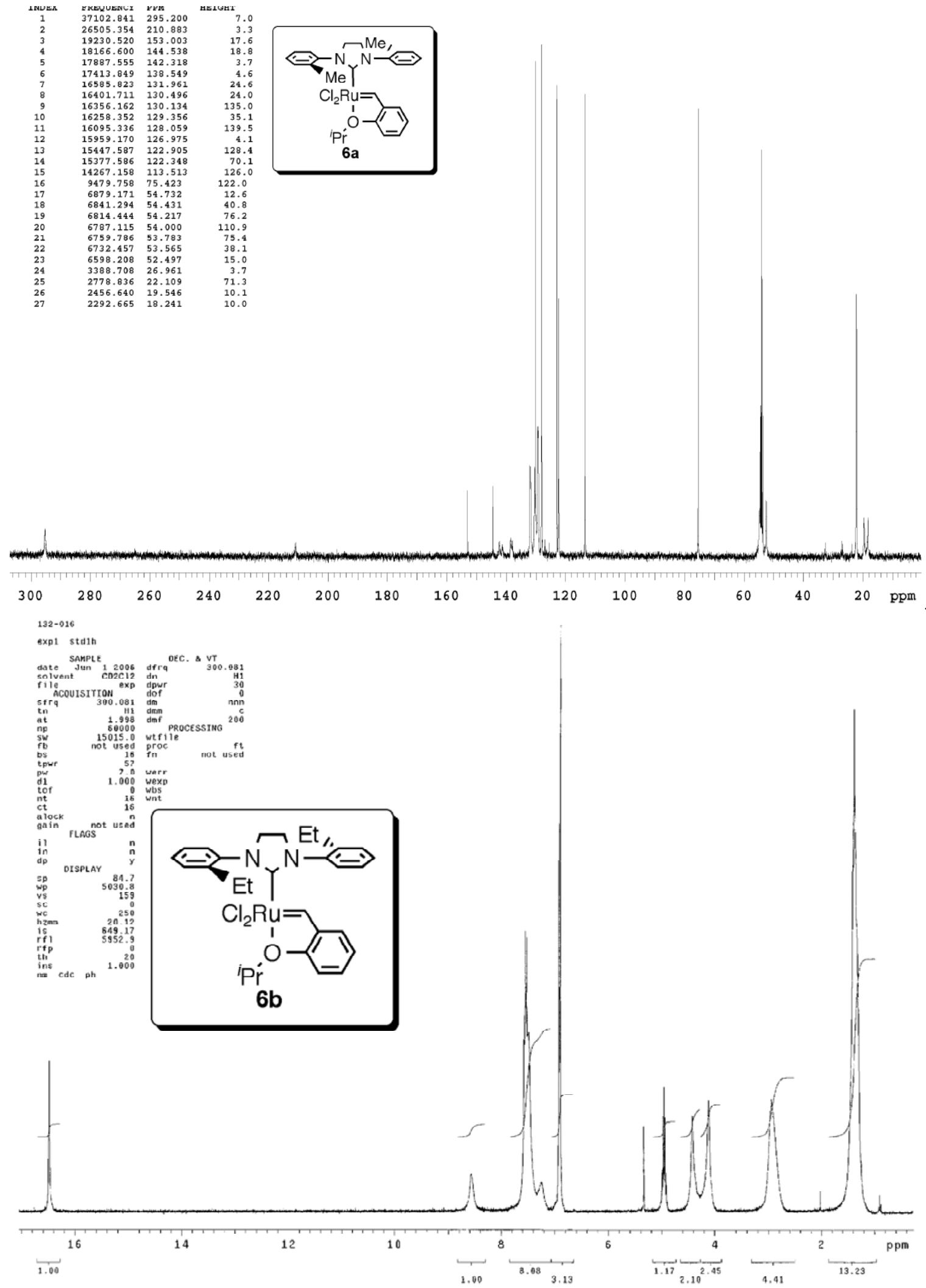


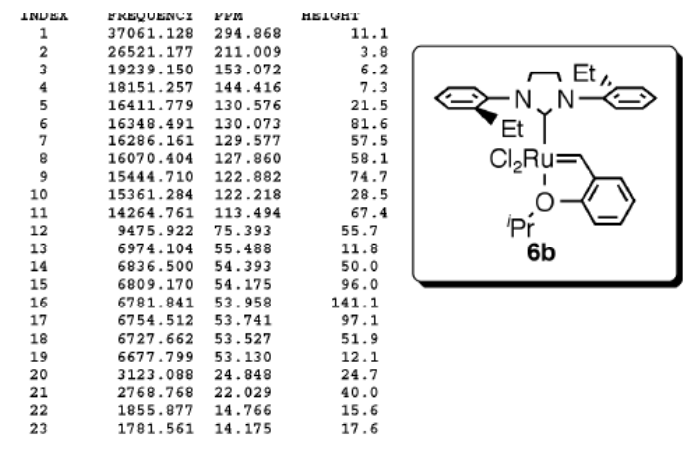

62-195
exp1 std1h
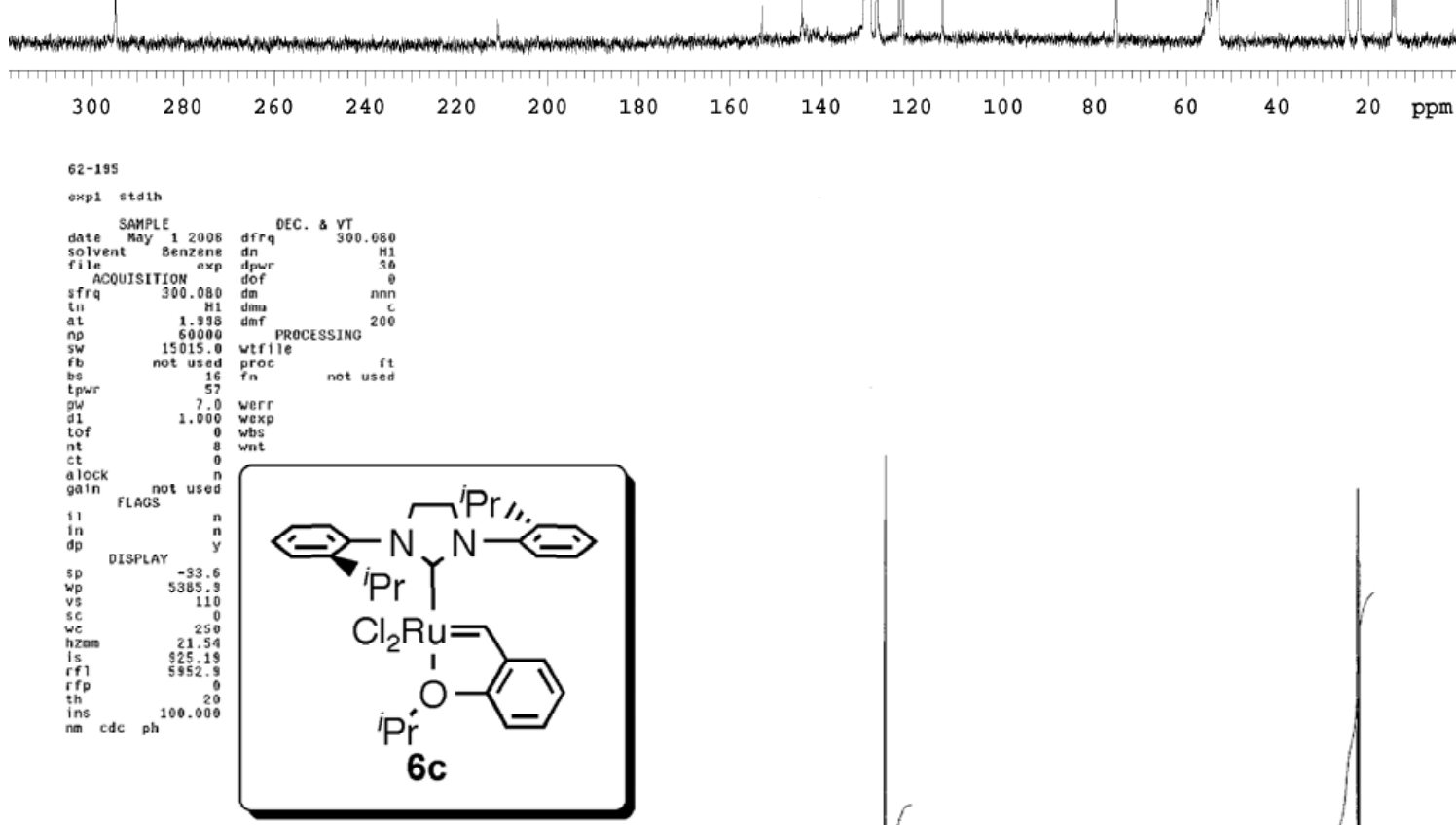

(6)




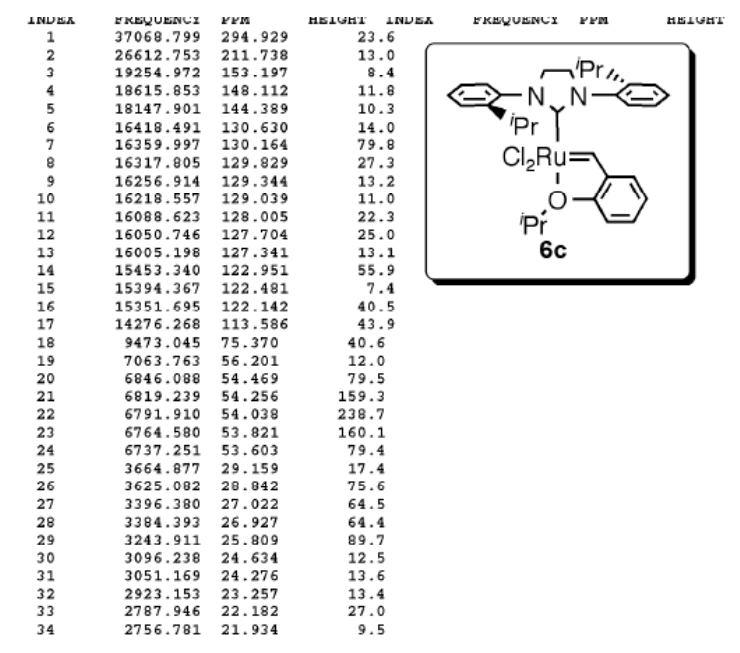

\section{List of Tables}

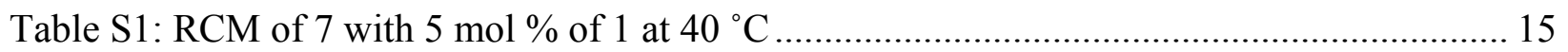

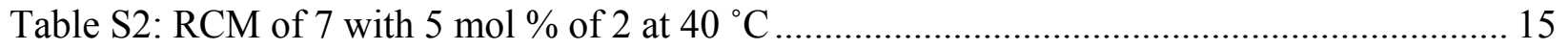

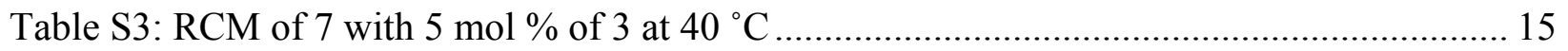

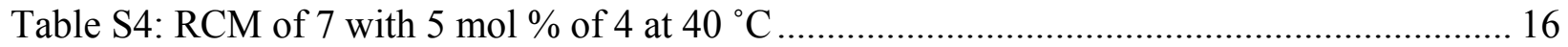

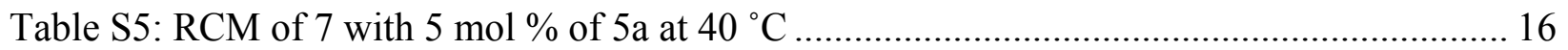

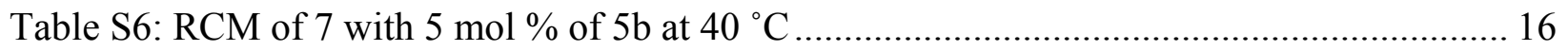

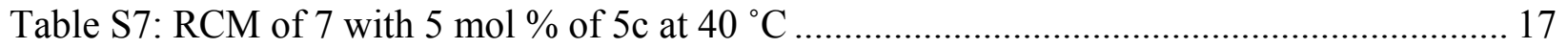

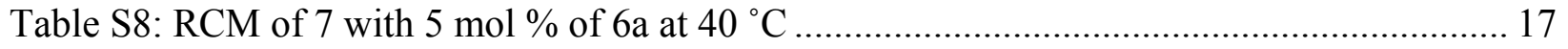

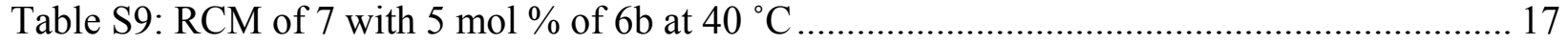

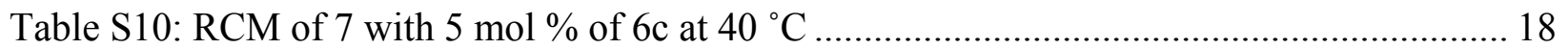

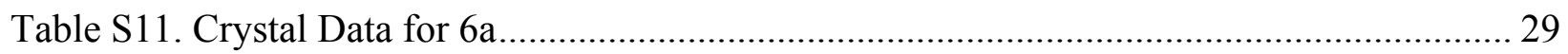

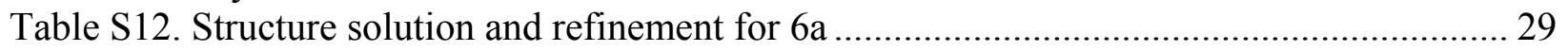

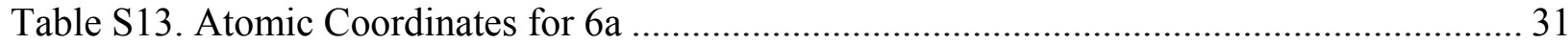

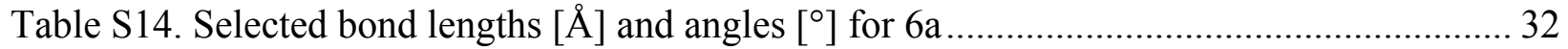

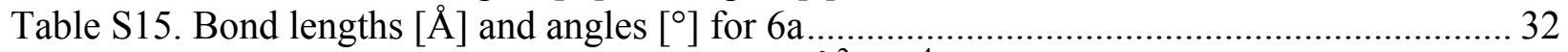

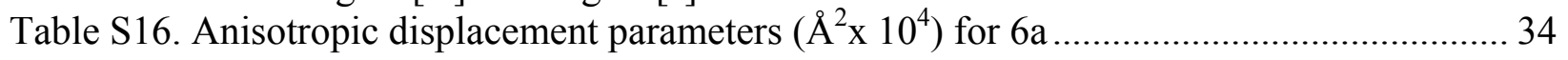

\section{List of Figures}

Figure S1. RCM of S1 using catalysts 1 and $5 \mathrm{a}\left(1 \mathrm{~mol} \%, 30{ }^{\circ} \mathrm{C}, \mathrm{CD}_{2} \mathrm{Cl}_{2}\right)$........................... 19

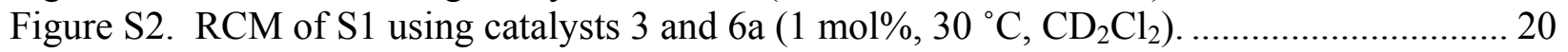

Figure S3. RCM of S3 using catalysts 1 and $5 \mathrm{a}\left(1 \mathrm{~mol} \%, 30{ }^{\circ} \mathrm{C}, \mathrm{CD}_{2} \mathrm{Cl}_{2}\right)$......................... 21

Figure S4. RCM of S3 using catalysts 3 and $6 \mathrm{a}\left(1 \mathrm{~mol} \%, 30{ }^{\circ} \mathrm{C}, \mathrm{CD}_{2} \mathrm{Cl}_{2}\right)$.......................... 22

Figure S5. RCM of 9 using catalysts 1 and $5 \mathrm{a}\left(5 \mathrm{~mol} \%, 30{ }^{\circ} \mathrm{C}, \mathrm{CD}_{2} \mathrm{Cl}_{2}\right)$. .......................... 23

Figure S6. RCM of 9 using catalysts 4 and $6 \mathrm{a}\left(5 \mathrm{~mol} \%, 30{ }^{\circ} \mathrm{C}, \mathrm{CD}_{2} \mathrm{Cl}_{2}\right)$. ........................ 24 


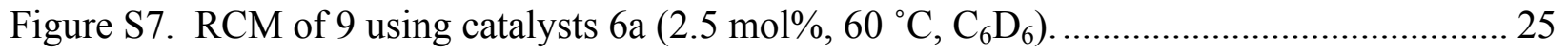

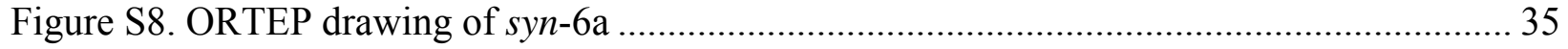

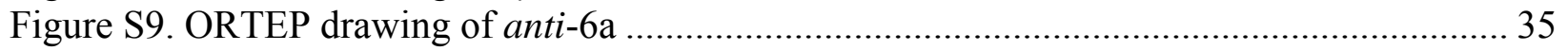

Figure S10. ORTEP drawing of superimposed syn- and anti-6a......................................... 36 


\section{GENERAL INFORMATION}

NMR spectra were recorded on an Oxford $300 \mathrm{MHz}$ NMR spectrometer running Varian VNMR software. Chemical shifts are reported in parts per million (ppm) downfield from tetramethylsilane (TMS) with reference to internal solvent for ${ }^{1} \mathrm{H}$ NMR and ${ }^{13} \mathrm{C}$ NMR spectra. Chemical shifts are reported in parts per million (ppm) downfield from $\mathrm{H}_{3} \mathrm{PO}_{4}$ for ${ }^{31} \mathrm{P}$ NMR spectra. Multiplicities are abbreviated as follows: singlet ( $\mathrm{s}$ ), doublet (d), triplet ( $\mathrm{t}$ ), quartet (q), quintet (quint), septet (sept), multiplet (m), and broad (br). Analytical thin-layer chromatography (TLC) was performed using silica gel $60 \mathrm{~F} 254$ precoated plates $(0.25 \mathrm{~mm}$ thickness) with a fluorescent indicator. Visualization was performed with standard potassium permanganate stains or UV light. Flash column chromatography of organic compounds was performed using silica gel 60 (230-400 mesh), and flash column chromatography of ruthenium compounds was performed using silica gel 60 (230-400 mesh) from TSI Scientific (Cambridge, MA). All glassware was either oven dried or flame dried, and reactions were done under an atmosphere of argon unless otherwise noted. All organic solvents were dried by passage through solvent purification columns containing activated alumina. All commercial chemicals were used as obtained. Dichloro(phenylmethylene)bis(tricyclo-hexylphosphine) ruthenium complex was prepared according to a literature procedure. ${ }^{\mathrm{i}}$

X-ray crystallographic structures were obtained by Mr. Larry M. Henling and Dr. Mike W. Day of the California Institute of Technology Beckman Institute X-Ray Crystallography Laboratory. 


\section{GENERAL PROCEDURE FOR THE PREPARATION OF $N, N$ '-DIARYL OXAMIDES}

Oxalyl chloride $(4.36 \mathrm{~mL}, 50 \mathrm{mmol})$ was added dropwise to a stirred solution of aniline (100 mmol, 2 equiv) and base (100 mmol, 2 equiv) in THF $(200 \mathrm{~mL})$ at $0{ }^{\circ} \mathrm{C}$. Triethylamine or aqueous $\mathrm{NaOH}$ may be used as bases for this reaction. Upon addition, the reaction was allowed to warm up to room temperature and stirred for $1 \mathrm{~h}$. The reaction mixture was then concentrated in vacuo and diluted with water $(100 \mathrm{~mL})$. The white precipitate was collected by filtration, washed with dilute $\mathrm{HCl}(100 \mathrm{~mL})$, water $(2 \times 100 \mathrm{~mL})$, and dried in vacuo.

\section{GENERAL PROCEDURE FOR THE PREPARATION OF $N, N^{\prime}$-DIARYLETHYLENEDIAMINE HYDROCHLORIDE}

Borane-tetrahydrofuran complex (1.0 M solution in THF, $125 \mathrm{~mL}, 6.25$ equiv) was added dropwise with stirring to solid oxamide $(20 \mathrm{mmol})$ at room temperature. The reaction mixture was refluxed overnight, allowed to cool to r.t. and excess borane was quenched by careful, dropwise addition of water until no more gas evolution was observed. The reaction mixture was concentrated in vacuo, extracted with ether and the organic extracts were dried over $\mathrm{Na}_{2} \mathrm{SO}_{4}$. $2 \mathrm{M} \mathrm{HCl}$ in ether $(30 \mathrm{~mL}, 3$ equiv) was then added to the dry organic extracts and the resulting white precipitate was collected by filtration, washed with a small amount of ethanol and dried in vacuo.

\section{GENERAL PROCEDURE FOR THE PREPARATION OF IMIDAZOLINIUM CHLORIDE}

Triethyl orthoformate $(150 \mathrm{~mL})$ was added to the diamine hydrochloride 3 in a $250 \mathrm{~mL}$ r.b. flask. The flask was equipped with a distillation head and heated for about $1 \mathrm{~h}$, during which ethanol distilled over at $78-80{ }^{\circ} \mathrm{C}$, followed by about $70 \mathrm{~mL}$ of triethyl orthoformate at $135-140{ }^{\circ} \mathrm{C}$. The reaction mixture was then allowed to cool to r.t., diluted with hexanes and the white precipitate was collected by filtration, washed with hexanes and ether and dried in vacuo. The following dihydroimidazolium salts were prepared by this procedure:

1,3-Bis(o-tolyl)-imidazolinium chloride. Obtained in 93\% yield as a white solid. ${ }^{1} \mathrm{H}$ NMR $\left(300 \mathrm{MHz}, \mathrm{CDCl}_{3}\right): \delta 8.83(\mathrm{~s}, 1 \mathrm{H}), 7.78-7.21(\mathrm{~d}, 8 \mathrm{H}), 4.64(\mathrm{~s}, 4 \mathrm{H}), 2.43(\mathrm{~s}, 6 \mathrm{H}) .{ }^{13} \mathrm{C}\left\{{ }^{1} \mathrm{H}\right\}$ NMR (75.41 MHz, $\left.\mathrm{CDCl}_{3}\right): \delta 157.48,134.37,133.44,131.57,129.82,127.64,126.68,52.89$, 18.12. HR-MS $\left(\mathrm{FAB}^{+}\right)$Calculated for $\mathrm{C}_{17} \mathrm{H}_{19} \mathrm{~N}_{2}$, 251.1548; found, 251.1557. 
1,3-Bis(2-ethylphenyl)-imidazolinium chloride. Obtained in $74 \%$ yield as a white solid. ${ }^{1} \mathrm{H}$ NMR (300 MHz, $\left.\mathrm{CD}_{2} \mathrm{Cl}_{2}\right) \delta 9.04(1 \mathrm{H}, \mathrm{s}), 7.92(2 \mathrm{H}, \mathrm{d}, J=7.5 \mathrm{~Hz}), 7.47-7.30(6 \mathrm{H}, \mathrm{m})$, $4.64(4 \mathrm{H}, \mathrm{s}), 2.78(4 \mathrm{H}, \mathrm{q}, J=7.8 \mathrm{~Hz}), 1.31(6 \mathrm{H}, \mathrm{t}, J=7.8 \mathrm{~Hz})$.

1,3-Bis(2-isopropylphenyl)-imidazolinium chloride. Obtained in $84 \%$ yield as a white solid. ${ }^{1} \mathrm{H}$ NMR $\left(300 \mathrm{MHz}, \mathrm{CDCl}_{3}\right): \delta 8.22\left(\mathrm{~d},{ }^{3} J_{\mathrm{HH}}=7.2 \mathrm{~Hz}, 2 \mathrm{H}\right), 8.04(\mathrm{~s}, 1 \mathrm{H}), 7.34(\mathrm{~m}, 6 \mathrm{H})$, $4.73(\mathrm{~s}, 4 \mathrm{H}), 3.06(\mathrm{~m}, 2 \mathrm{H}), 1.29\left(\mathrm{~d},{ }^{3} J_{\mathrm{HH}}=6.0 \mathrm{~Hz}, 12 \mathrm{H}\right)$.

\section{GENERAL PROCEDURE FOR THE PREPARATION OF CATALYSTS 5A-C}

Potassium bis(trimethylsilyl)amide (1.4 g, $7.0 \mathrm{mmol}, 1.23$ equiv) was added to a suspension of the appropriate imidazolinium chloride $(6.7 \mathrm{mmol}, 1.15$ equiv) in toluene $(60 \mathrm{~mL})$ under argon. The reaction mixture was stirred at room temperature for $30 \mathrm{~min}$, then dichloro(phenylmethylene)bis(tricyclohexylphosphine) ruthenium complex (4.7 g, $5.7 \mathrm{mmol}$ ) was added and stirring was continued for $1.5 \mathrm{~h}$ at room temperature. The reaction mixture was then concentrated and catalysts 5a-c were purified by column chromatography on silica gel: unreacted dichloro(phenylmethylene)bis(tricyclo-hexylphosphine) ruthenium complex was first eluted with 1:9 EtOAc-hexanes, then 5a-c were eluted with 1:3 EtOAc-hexanes. The catalysts were obtained as brown solids upon drying in vacuo.

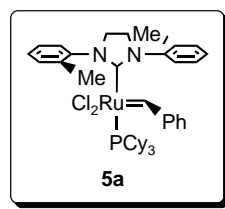

Catalyst 5a. 5a was prepared according to the above general procedure and was obtained in $66 \%$ yield. ${ }^{1} \mathrm{H}$ NMR $\left(300 \mathrm{MHz}, \mathrm{C}_{6} \mathrm{D}_{6}\right): \delta 19.61$ (s), 8.70 (br), 7.64 (br), 7.31 $6.76(\mathrm{~m}), 6.59(\mathrm{~m}), 6.34(\mathrm{br}), 3.53-3.01(\mathrm{~m}), 2.62$ (s), 2.20-2.04 (br), 1.67-1.06 (m). ${ }^{31} \mathrm{P}\left\{{ }^{1} \mathrm{H}\right\}$ NMR (121 MHz, $\left.\mathrm{C}_{6} \mathrm{D}_{6}\right): \delta 27.87$ (s), $25.15(\mathrm{~s}) .{ }^{13} \mathrm{C}\left\{{ }^{1} \mathrm{H}\right\} \mathrm{NMR}\left(125 \mathrm{MHz}, \mathrm{CD}_{2} \mathrm{Cl}_{2}\right): \delta 18.47$, 19.47, 26.67, 27.50 (d, $J=12 \mathrm{~Hz}), 28.14$ (d, $J=10 \mathrm{~Hz}), 29.13$ (d, $J=12 \mathrm{~Hz}), 32.71$ (d, $J=16$ Hz), 53.78 (br), 126.69, 128.28 (br), 128.84, 129.03, 129.73, 130.06, 131.85, 136.63, 138.42, 139.69, 141.13, 151.19, 219.49 (m), 297.66 (m). HR-MS (FAB ${ }^{+}$) Calculated for $\mathrm{C}_{42} \mathrm{H}_{57} \mathrm{~N}_{2} \mathrm{Cl}_{2} \mathrm{PRu}, 792.2680$; found, 792.2678. 


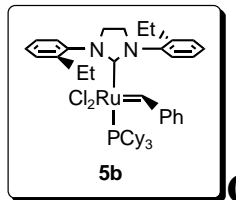

Catalyst 5b. 5b was prepared according to the above general procedure and was obtained in $60 \%$ yield. ${ }^{1} \mathrm{H}$ NMR $\left(300 \mathrm{MHz}, \mathrm{C}_{6} \mathrm{D}_{6}\right): \delta 19.59(\mathrm{~s}), 8.74-8.62(\mathrm{~m}), 8.25$ (br), 7.71 (br), 7.34-6.85 (m), 6.67 (br), 6.44 (br), 3.55-3.07 (m), 2.79-2.19 (m), 1.69-0.91 (m), 1.67$1.06(\mathrm{~m}) .{ }^{31} \mathrm{P}\left\{{ }^{1} \mathrm{H}\right\}$ NMR (121 MHz, $\left.\mathrm{C}_{6} \mathrm{D}_{6}\right): \delta 25.75$ (s), $25.04(\mathrm{~s}) .{ }^{13} \mathrm{C} \mathrm{NMR}(125 \mathrm{MHz}$, $\left.\mathrm{CD}_{2} \mathrm{Cl}_{2}\right): \delta 13.96,23.71,24.44,26.72,27.47(\mathrm{~d}, J=12 \mathrm{~Hz}) 28.15$ (d, $\left.J=10 \mathrm{~Hz}\right), 29.12$ (br), 32.73 (d, $J=16 \mathrm{~Hz}$ ), 54.50 (br), 126.50, 127.86, 128.28, 128.37, 128.98, 129.38, 129.86, 130.21, 131.56 (br), 143.70, 151.13, 220.26 (m), 295.55 (m). HR-MS (FAB ${ }^{+}$) Calculated for $\mathrm{C}_{44} \mathrm{H}_{61} \mathrm{~N}_{2} \mathrm{Cl}_{2} \mathrm{PRu}, 820.2993$; found, 920.2951.

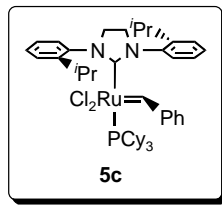

Catalyst 5c. 5c was prepared according to the above general procedure and was obtained in 68\% yield. ${ }^{1} \mathrm{H}$ NMR $\left(300 \mathrm{MHz}, \mathrm{C}_{6} \mathrm{D}_{6}\right): \delta 19.68$ (s), 19.49 (s), 8.93-8.87 (m), 8.30 (b), 7.60 (d), 7.34-7.12 (m), 6.97 (t), 6.80 (d), 6.70-6.44 (m), 3.85-3.08 (m), 2.22-2.12 (q), 2.02-1.91 (q), 1.66-0.97 (m). ${ }^{31} \mathrm{P}\left\{{ }^{1} \mathrm{H}\right\}$ NMR (121 MHz, $\left.\mathrm{C}_{6} \mathrm{D}_{6}\right): \delta 26.33$ (s), 23.92 (s). ${ }^{13} \mathrm{C}\left\{{ }^{1} \mathrm{H}\right\}$ NMR (125 MHz, $\left.\mathrm{CD}_{2} \mathrm{Cl}_{2}\right): \delta 23.51,23.60,25.67,25.79,25.87,26.68(\mathrm{~d}, J=13 \mathrm{~Hz}), 27.34$, 27.43, $28.12(\mathrm{~d}, J=10 \mathrm{~Hz}), 28.42,28.95$ (d, $J=13 \mathrm{~Hz}), 32.72(\mathrm{~d}, J=19 \mathrm{~Hz}), 32.85$ (d, $J=16$ Hz), 55.33, 56.14, 126.35, 126.72, 127.01, 127.68, 127.91, 128.13, 128.36, 128.80, 128.91, $129.02,129.12$, 129.77, 130.04, 130.71, 130.83, 132.08, 138.33, 138.53, 139.65, 139.85, 146.23, 146.23, 146.88, 148.24, 148.30, 151.06, 151.61, 221.51 (d, $J=76$ Hz), 296.66 (m). HR-MS $\left(\mathrm{FAB}^{+}\right.$) Calculated for $\mathrm{C}_{46} \mathrm{H}_{65} \mathrm{~N}_{2} \mathrm{Cl}_{2} \mathrm{PRu}, 848.3306$; found, 848.3326.

\section{GENERAL PROCEDURE FOR THE PREPARATION OF CATALYSTS 6A-C.}

2-Isopropoxy- $\beta$-methylstyrene ( $0.89 \mathrm{~g}, 5.1 \mathrm{mmol}, 2$ equiv) was added to a solution of catalyst 5 ( $2.5 \mathrm{mmol})$ in $\mathrm{CH}_{2} \mathrm{Cl}_{2}(25 \mathrm{~mL})$. The reaction mixture was refluxed for $1 \mathrm{~h}$, then a $2.0 \mathrm{~N}$ solution of $\mathrm{HCl}$ in methanol (1.8 mL, $3.6 \mathrm{mmol}, 1.5$ equiv) was added and the mixture was refluxed for another hour, followed by evaporation to dryness in vacuo. The residue was dissolved in a minimal amount of $\mathrm{CH}_{2} \mathrm{Cl}_{2}$ and catalyst 6 was precipitated by addition of pentane. The solids were collected by filtration and the catalysts purified by column chromatography on silica gel 
(eluted with 1:5 EtOAc-hexanes). The catalysts were obtained as green crystalline solids upon drying in vacuo.

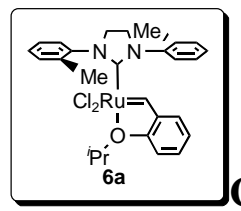

Catalyst 6a. 6a was prepared according to the above general procedure and was obtained in 71\% yield. ${ }^{1} \mathrm{H}$ NMR $\left(300 \mathrm{MHz}, \mathrm{CD}_{2} \mathrm{Cl}_{2}\right): \delta 16.47(\mathrm{~s}, 1 \mathrm{H}), 8.59(\mathrm{~s}, 1 \mathrm{H}), 7.43(\mathrm{br}$, $8 \mathrm{H}), 6.91\left(\mathrm{~d},{ }^{3} J_{\mathrm{HH}}=5.1 \mathrm{~Hz}, 3 \mathrm{H}\right), 4.97(\mathrm{~m}, 1 \mathrm{H}), 4.38(\mathrm{~s}, 2 \mathrm{H}), 4.10(\mathrm{~s}, 2 \mathrm{H}), 2.53(\mathrm{~s}, 6 \mathrm{H}), 1.34(\mathrm{br}$, $6 \mathrm{H}) .{ }^{13} \mathrm{C}\left\{{ }^{1} \mathrm{H}\right\} \mathrm{NMR}\left(125 \mathrm{MHz}, \mathrm{CD}_{2} \mathrm{Cl}_{2}\right): \delta 18.24,19.55,22.11,52.50,54.73,75.42,113.51$, 122.35, 122.91, 128.06, 129.36, 130.13, 130.50, 131.97, 138.56 (m), 142.32, 144.54, 153.00, 210.89, 295.21. HR-MS (FAB ${ }^{+}$) Calculated for $\mathrm{C}_{27} \mathrm{H}_{30} \mathrm{~N}_{2} \mathrm{Cl}_{2} \mathrm{OPRu}, 570.0779$; found, 570.0788.

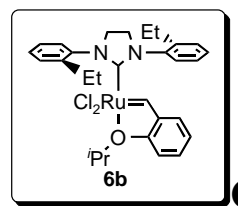

Catalyst 6b. 6b was prepared according to the above general procedure and was obtained in $68 \%$. ${ }^{1} \mathrm{H}$ NMR $\left(300 \mathrm{MHz}, \mathrm{CD}_{2} \mathrm{Cl}_{2}\right)$ : $\delta 16.48(\mathrm{~s}, 1 \mathrm{H}), 8.56(\mathrm{br}, 1 \mathrm{H}), 7.53(\mathrm{~m}$, $8 \mathrm{H}), 6.89\left(\mathrm{~d},{ }^{3} J_{\mathrm{HH}}=6.6 \mathrm{~Hz}, 3 \mathrm{H}\right), 4.95(\mathrm{~m}, 1 \mathrm{H}), 4.42(\mathrm{~s}, 2 \mathrm{H}), 4.10(\mathrm{~s}, 2 \mathrm{H}), 2.93(\mathrm{br}, 4 \mathrm{H}), 1.37$ (br, $12 \mathrm{H}) .{ }^{13} \mathrm{C}\left\{{ }^{1} \mathrm{H}\right\}$ NMR $\left(125 \mathrm{MHz}, \mathrm{CD}_{2} \mathrm{Cl}_{2}\right): \delta 14.22,14.80,24.86,53.17,55.41,75.44,113.54$, 122.26, 122.92, 127.91, 129.91, 130.12, 130.62, 144.47, 153.11, 211.06, 294.93. HR-MS (FAB $\left.{ }^{+}\right)$ Calculated for $\mathrm{C}_{29} \mathrm{H}_{34} \mathrm{~N}_{2} \mathrm{Cl}_{2} \mathrm{ORu}$, 598.1092; found, 598.1109.

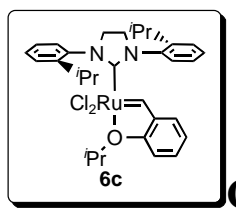

Catalyst 6c. 6c was prepared according to the above general procedure and was obtained in $77 \%$ yield. ${ }^{1} \mathrm{H}$ NMR $\left(300 \mathrm{MHz}, \mathrm{C}_{6} \mathrm{D}_{6}\right): \delta 16.65$ (s), 16.46 (s), $9.18(\mathrm{~m}), 7.90$ (d), 7.40-6.93 (m), $6.59(\mathrm{t}), 6.34\left(\mathrm{~d},{ }^{3} J_{\mathrm{HH}}=7.5 \mathrm{~Hz}\right), 4.47(\mathrm{~m}), 3.80-3.32(\mathrm{~m}), 2.66(\mathrm{br}), 1.95-1.12(\mathrm{~m})$. ${ }^{13} \mathrm{C}\left\{{ }^{1} \mathrm{H}\right\}$ NMR (125 MHz, $\left.\mathrm{CD}_{2} \mathrm{Cl}_{2}\right): \delta 22.14(\mathrm{~m}), 23.22,24.24,24.60,25.77,26.89,26.98,28.80$, 29.12, 56.16, 75.33, 113.55, 122.10, 122.44, 122.91, 127.30, 127.67, 127.97, 129.00, 129.31, $129.79,130.13,130.59,140.79$ (m), 144.35, 148.07, 153.16, 211.70, 294.89. HR-MS (FAB $\left.{ }^{+}\right)$ Calculated for $\mathrm{C}_{31} \mathrm{H}_{38} \mathrm{~N}_{2} \mathrm{Cl}_{2} \mathrm{ORu}, 626.1405$; found, 626.1365 . 


\section{GENERAL PROCEDURE FOR THE RCM OF 7 (MONITORED BY GC)}

A round bottom flask filled with an atmosphere of argon was charged with a degassed solution of dimethyl 2,2-di(2-methylallyl)malonate (7) in $\mathrm{CH}_{2} \mathrm{Cl}_{2}(0.1 \mathrm{M})$. The catalyst was added as a solid ( $5 \mathrm{~mol} \%$ ) and the flask was equipped with a reflux condenser and a bubbler outlet. The reaction vessel was immerged in an oil bath heated at the desired temperature. The progress of conversion to product was monitored by GC analysis after removing the catalyst by treating the aliquot with a solution of tris(hydroxymethyl)phosphine in isopropanol $(1.0 \mathrm{M})$, heating the quenched mixture at $60{ }^{\circ} \mathrm{C}$ for $1 \mathrm{~h}$, diluting it with water and extracting with ethyl acetate.

The reaction mixtures were analyzed by gas chromatography (GC) using a flame ionization detector (FID). The following conditions and equipment were used:

Column: $\quad$ Rtx- $5,30 \mathrm{~m} \times 0.25 \mathrm{~mm}$ (ID) $\mathrm{x} 0.25 \mu \mathrm{m}$ film thickness. Manufacturer: Restek

$\mathrm{GC}$ and column conditions: Injector temperature: $250^{\circ} \mathrm{C}$

Detector temperature: $280^{\circ} \mathrm{C}$

Oven temperature: $\quad$ Starting temperature: $100^{\circ} \mathrm{C}$, hold time: 1 minute.

Ramp rate $10^{\circ} \mathrm{C} / \mathrm{min}$ to $250^{\circ} \mathrm{C}$, hold time: 12 minutes.

Carrier gas: Helium

Mean gas velocity: $\quad 31.3 \pm 3.5 \% \mathrm{~cm} / \mathrm{sec}$ (calculated)

Split ratio: $\quad \sim 50: 1$

The product percentages given in Table 1 and Tables S1-S10 were determined by dividing the GC area of the product by the sum of the GC areas of product and substrate. The accuracy of this method was assessed by analyzing mixtures of substrate and product of known ratios. It was established that this method gives product percentages with $95 \%$ accuracy (above $80 \%$ conversion) and with $90 \%$ accuracy (below $80 \%$ conversion). 


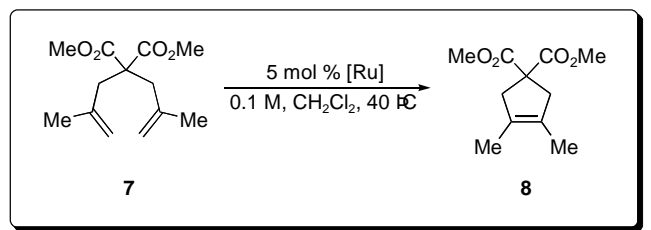

Table S1: RCM of 7 with $5 \mathrm{~mol} \%$ of 1 at $40{ }^{\circ} \mathrm{C}$

\begin{tabular}{|c|c|}
\hline Time (h) & Product (GC\%) \\
\hline 0.5 & 3.0 \\
\hline 1 & 4.2 \\
\hline 3 & 15.7 \\
\hline 18 & 44.7 \\
\hline 24 & 49.8 \\
\hline 42 & 54.5 \\
\hline
\end{tabular}

Table S2: RCM of 7 with $5 \mathrm{~mol} \%$ of 2 at $40{ }^{\circ} \mathrm{C}$

\begin{tabular}{|c|c|}
\hline Time (h) & Product (GC\%) \\
\hline 0.5 & 4.7 \\
\hline 1 & 9.1 \\
\hline 3 & 22.0 \\
\hline 24 & 40.4 \\
\hline 72 & 40.9 \\
\hline
\end{tabular}

Table S3: RCM of 7 with $5 \mathrm{~mol} \%$ of 3 at $40{ }^{\circ} \mathrm{C}$

\begin{tabular}{|c|c|}
\hline Time (h) & Product (GC\%) \\
\hline 0.5 & 0.0 \\
\hline 1 & 0.0 \\
\hline 2 & 0.0 \\
\hline 3 & 0.0 \\
\hline 20 & 0.0 \\
\hline 24 & 0.0 \\
\hline
\end{tabular}


Table S4: RCM of 7 with $5 \mathrm{~mol} \%$ of 4 at $40{ }^{\circ} \mathrm{C}$

\begin{tabular}{|c|c|}
\hline Time (h) & Product (GC \%) \\
\hline 0.5 & 0.0 \\
\hline 1 & 0.0 \\
\hline 2 & 2.6 \\
\hline 3 & 7.0 \\
\hline 20 & 24.2 \\
\hline
\end{tabular}

Table S5: RCM of 7 with $5 \mathrm{~mol} \%$ of $5 a$ at $40{ }^{\circ} \mathrm{C}$

\begin{tabular}{|c|c|}
\hline Time (h) & Product (GC\%) \\
\hline 0.25 & 80.9 \\
\hline 0.5 & 83.7 \\
\hline 0.75 & 85.4 \\
\hline 1 & 86.4 \\
\hline 1.5 & 87.5 \\
\hline 2 & 86.7 \\
\hline 4 & 86.8 \\
\hline
\end{tabular}

Table S6: RCM of 7 with $5 \mathrm{~mol} \%$ of $5 \mathbf{b}$ at $40{ }^{\circ} \mathrm{C}$

\begin{tabular}{|c|c|}
\hline Time (h) & Product (GC\%) \\
\hline 0.25 & 61.5 \\
\hline 0.5 & 69.9 \\
\hline 0.75 & 70.7 \\
\hline 1 & 70.9 \\
\hline 2 & 70.6 \\
\hline 4 & 72.3 \\
\hline 20 & 72.8 \\
\hline
\end{tabular}


Table S7: RCM of 7 with $5 \mathrm{~mol} \%$ of $5 \mathrm{c}$ at $40{ }^{\circ} \mathrm{C}$

\begin{tabular}{|c|c|}
\hline Time (h) & Product (GC\%) \\
\hline 0.25 & 71.5 \\
\hline 0.5 & 73.0 \\
\hline 0.75 & 73.1 \\
\hline 1 & 74.3 \\
\hline 1.5 & 75.0 \\
\hline 2 & 75.5 \\
\hline 4 & 75.1 \\
\hline
\end{tabular}

Table S8: RCM of 7 with $5 \mathrm{~mol} \%$ of $6 a$ at $40{ }^{\circ} \mathrm{C}$

\begin{tabular}{|c|c|}
\hline Time (h) & Product (GC\%) \\
\hline 0.5 & 30.6 \\
\hline 1 & 44.7 \\
\hline 3 & 65.1 \\
\hline 18 & 69.9 \\
\hline 24 & 70.0 \\
\hline 42 & 68.8 \\
\hline
\end{tabular}

Table S9: RCM of 7 with $5 \mathrm{~mol} \%$ of $6 \mathbf{b}$ at $40{ }^{\circ} \mathrm{C}$

\begin{tabular}{|l|l|}
\hline Time (h) & Product (GC \%) \\
\hline
\end{tabular}




\begin{tabular}{|c|c|}
\hline Time (h) & Product (GC\%) \\
\hline 0.25 & 0.7 \\
\hline 0.50 & 3.3 \\
\hline 0.75 & 11.8 \\
\hline 1 & 21.5 \\
\hline 2 & 34.7 \\
\hline 4 & 42.9 \\
\hline 8 & 55.9 \\
\hline 24 & 58.6 \\
\hline
\end{tabular}

Table S10: RCM of 7 with $5 \mathrm{~mol} \%$ of $6 \mathrm{c}$ at $40{ }^{\circ} \mathrm{C}$

\begin{tabular}{|c|c|}
\hline Time (h) & Product (GC\%) \\
\hline 0.25 & 0.7 \\
\hline 0.50 & 2.9 \\
\hline 0.75 & 9.3 \\
\hline 1 & 15.6 \\
\hline 1.5 & 24.2 \\
\hline 2 & 27.5 \\
\hline 6 & 32.0 \\
\hline 24 & 32.5 \\
\hline
\end{tabular}

\section{GENERAL PROCEDURE FOR ACTIVITY PLOTS OF RING-CLOSING METATHESIS. ii}

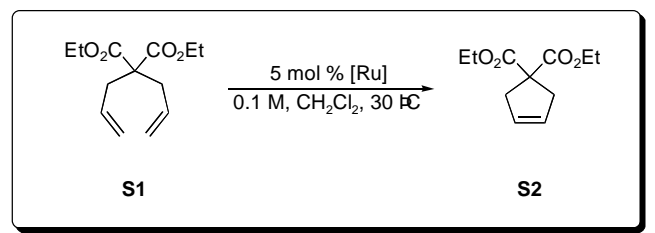

\section{RCM OF DIETHYL DIALLYLMALONATE (S1)}

An NMR tube with a screw-cap septum top was charged inside a glovebox with catalyst stock solution $(0.002 \mathrm{M}, 0.4 \mathrm{~mL}, 0.80 \mu \mathrm{mol}, 1.0 \mathrm{~mol} \%)$ and $\mathrm{CD}_{2} \mathrm{Cl}_{2}(0.4 \mathrm{~mL})$. The sample was equilibrated at $30^{\circ} \mathrm{C}$ in the NMR probe before $\mathbf{S 1}(19.3 \mu \mathrm{L}, 19.2 \mathrm{mg}, 0.080 \mathrm{mmol}, 0.1 \mathrm{M})$ was added via syringe. Data points were collected over an appropriate period of time using the 
Varian array function. The conversion to $\mathbf{S} 2$ was determined by comparing the ratio of the integrals of the methylene protons in the starting material, $\delta 2.61(\mathrm{dt})$, with those in the product, $\delta 2.98(\mathrm{~s})$.

Figure S1. RCM of S1 using catalysts 1 and $5 a\left(1 \mathrm{~mol} \%, 30{ }^{\circ} \mathrm{C}, \mathrm{CD}_{2} \mathrm{Cl}_{2}\right)$.

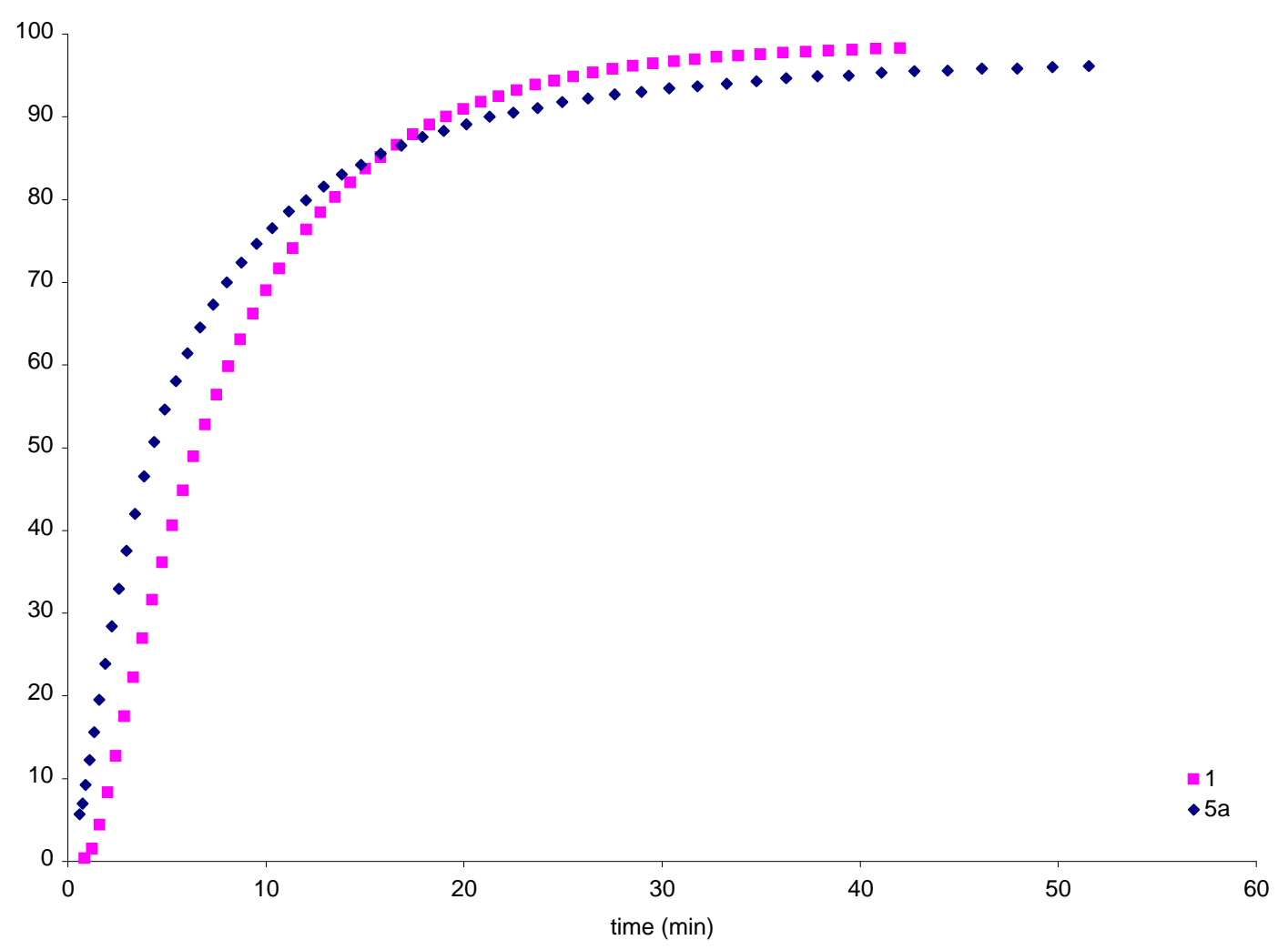


Figure S2. RCM of $\mathbf{S 1}$ using catalysts 3 and $\mathbf{6 a}\left(1 \mathrm{~mol} \%, 30{ }^{\circ} \mathrm{C}, \mathrm{CD}_{2} \mathrm{Cl}_{2}\right)$.

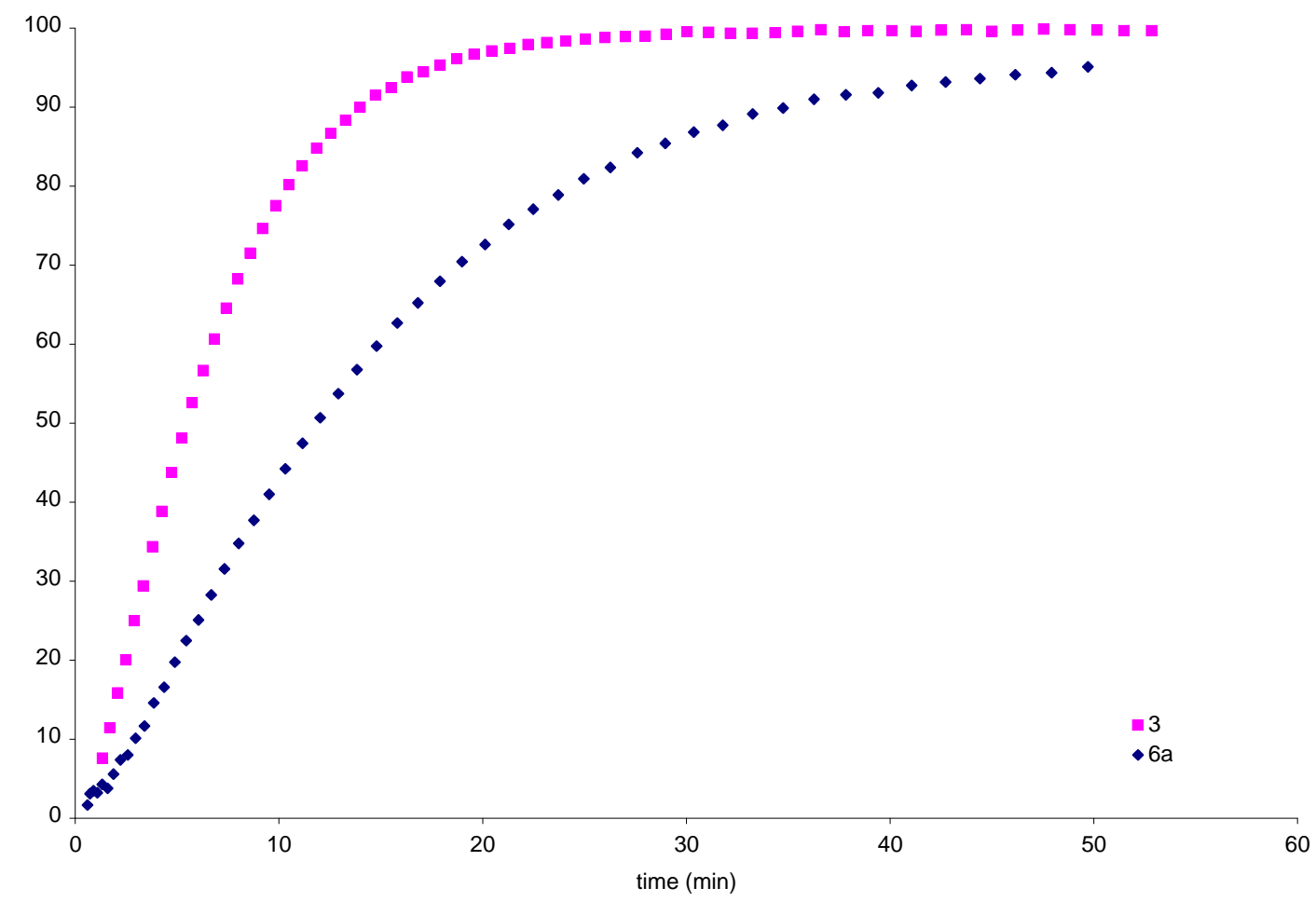




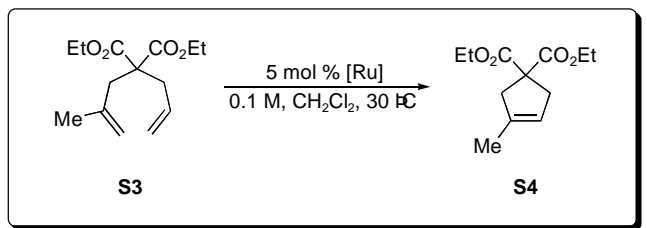

\section{RCM OF DIETHYL ALLYLMETHALLYLMALONATE (S3)}

An NMR tube with a screw-cap septum top was charged inside a glovebox with catalyst stock solution $(0.002 \mathrm{M}, 0.4 \mathrm{~mL}, 0.80 \mu \mathrm{mol}, 1.0 \mathrm{~mol} \%)$ and $\mathrm{CD}_{2} \mathrm{Cl}_{2}(0.4 \mathrm{~mL})$. The sample was equilibrated at $30^{\circ} \mathrm{C}$ in the NMR probe before S3 $(20.5 \mu \mathrm{L}, 20.4 \mathrm{mg}, 0.080 \mathrm{mmol}, 0.1 \mathrm{M})$ was added via syringe. Data points were collected over an appropriate period of time using the Varian array function. The conversion to S4 was determined by comparing the ratio of the integrals of the methylene protons in the starting material, $\delta 2.67(\mathrm{~s}), 2.64(\mathrm{dt})$, with those in the product, $\delta 2.93(\mathrm{~s}), 2.88(\mathrm{~m})$.

Figure S3. RCM of S3 using catalysts 1 and $5 a\left(1 \mathrm{~mol} \%, 30{ }^{\circ} \mathrm{C}, \mathrm{CD}_{2} \mathrm{Cl}_{2}\right)$.

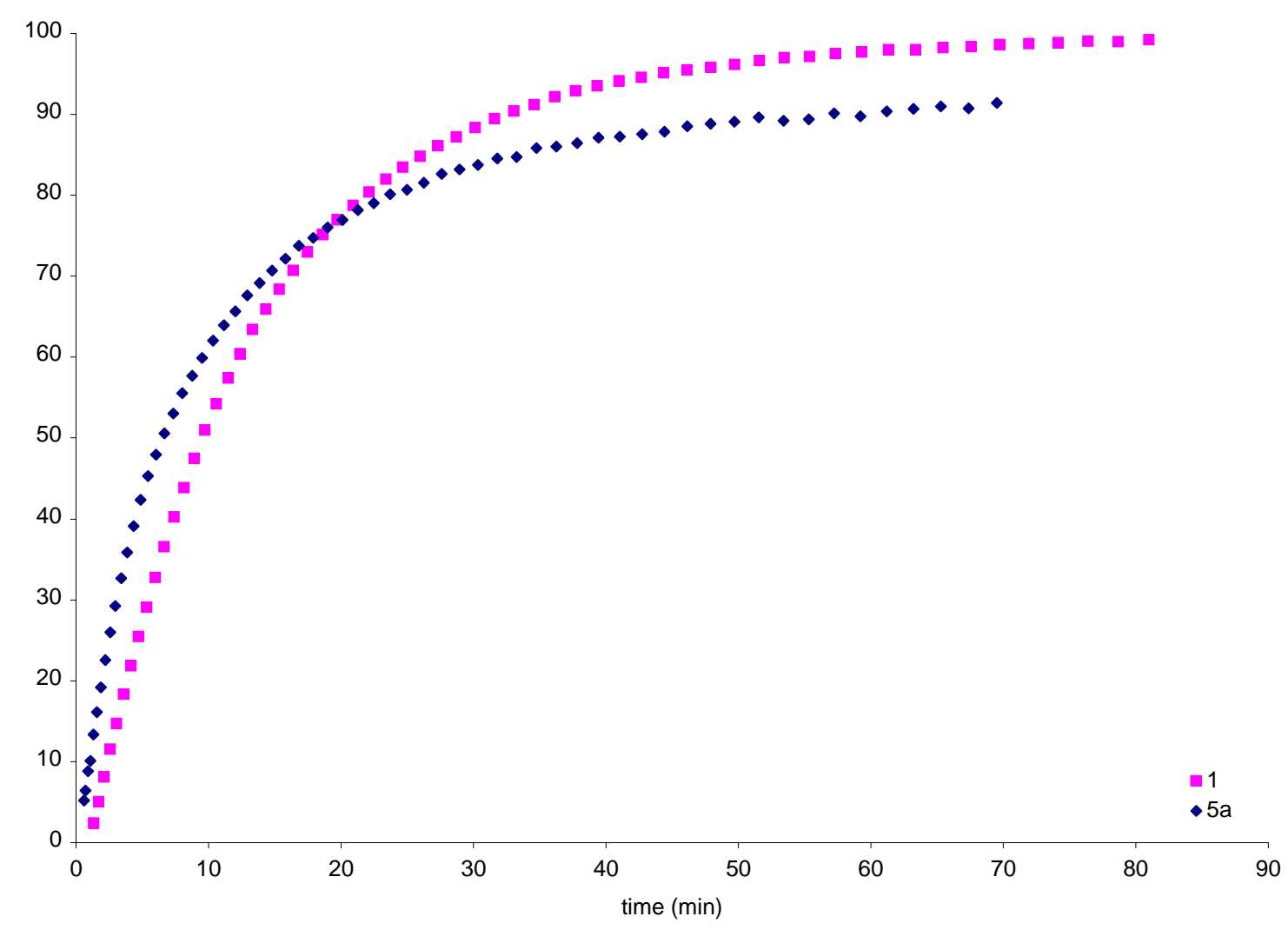


Figure S4. RCM of S3 using catalysts 3 and $\mathbf{6 a}\left(1 \mathrm{~mol} \%, 30{ }^{\circ} \mathrm{C}, \mathrm{CD}_{2} \mathrm{Cl}_{2}\right)$.

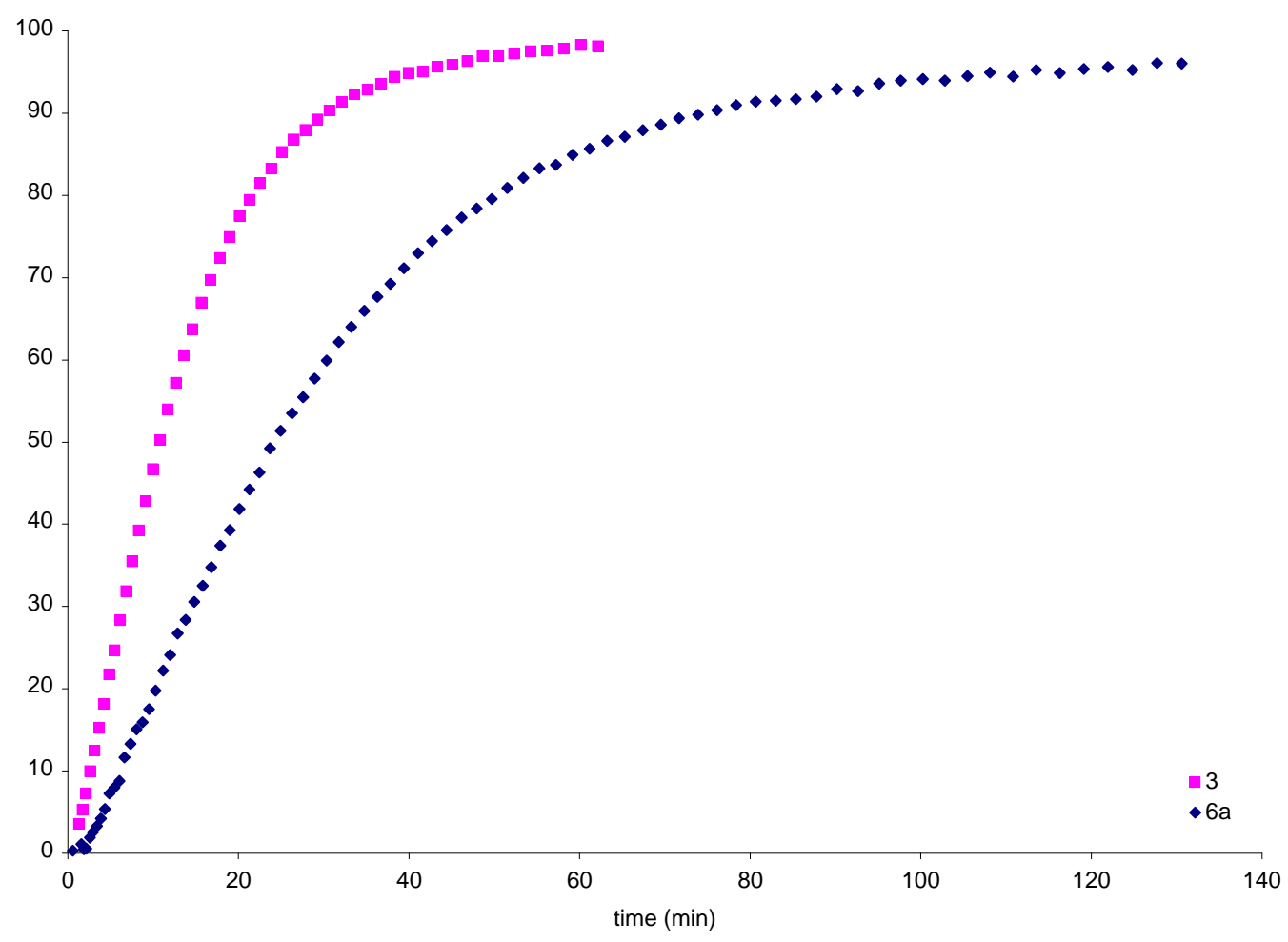




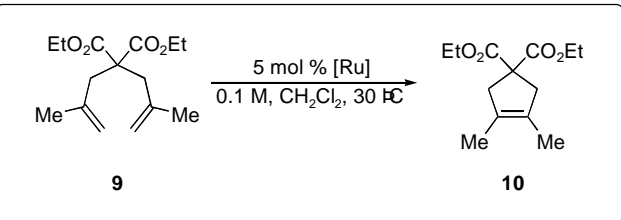

\section{RCM OF DIETHYL DIMETHALLYLMALONATE (9)}

An NMR tube with a screw-cap septum top was charged inside a glovebox with catalyst stock solution ( $0.005 \mathrm{M}$ in $\mathrm{C}_{6} \mathrm{D}_{6}$ or $\mathrm{CD}_{2} \mathrm{Cl}_{2}, 0.8 \mathrm{~mL}, 4.0 \mu \mathrm{mol}, 5.0 \mathrm{~mol} \%$ ). The sample was equilibrated at $30{ }^{\circ} \mathrm{C}$ or $60{ }^{\circ} \mathrm{C}$ in the NMR probe before $9(21.6 \mu \mathrm{L}, 21.5 \mathrm{mg}, 0.080 \mathrm{mmol}, 0.1 \mathrm{M})$ was added via syringe. Data points were collected over an appropriate period of time using the Varian array function. The conversion to $\mathbf{1 0}$ was determined by comparing the ratio of the integrals of the methylene protons in the starting material, $\delta 2.71$ (s), with those in the product, $\delta 2.89$ (s).

Figure S5. RCM of 9 using catalysts 1 and $5 a\left(5 \mathrm{~mol} \%, 30{ }^{\circ} \mathrm{C}, \mathrm{CD}_{2} \mathrm{Cl}_{2}\right)$.

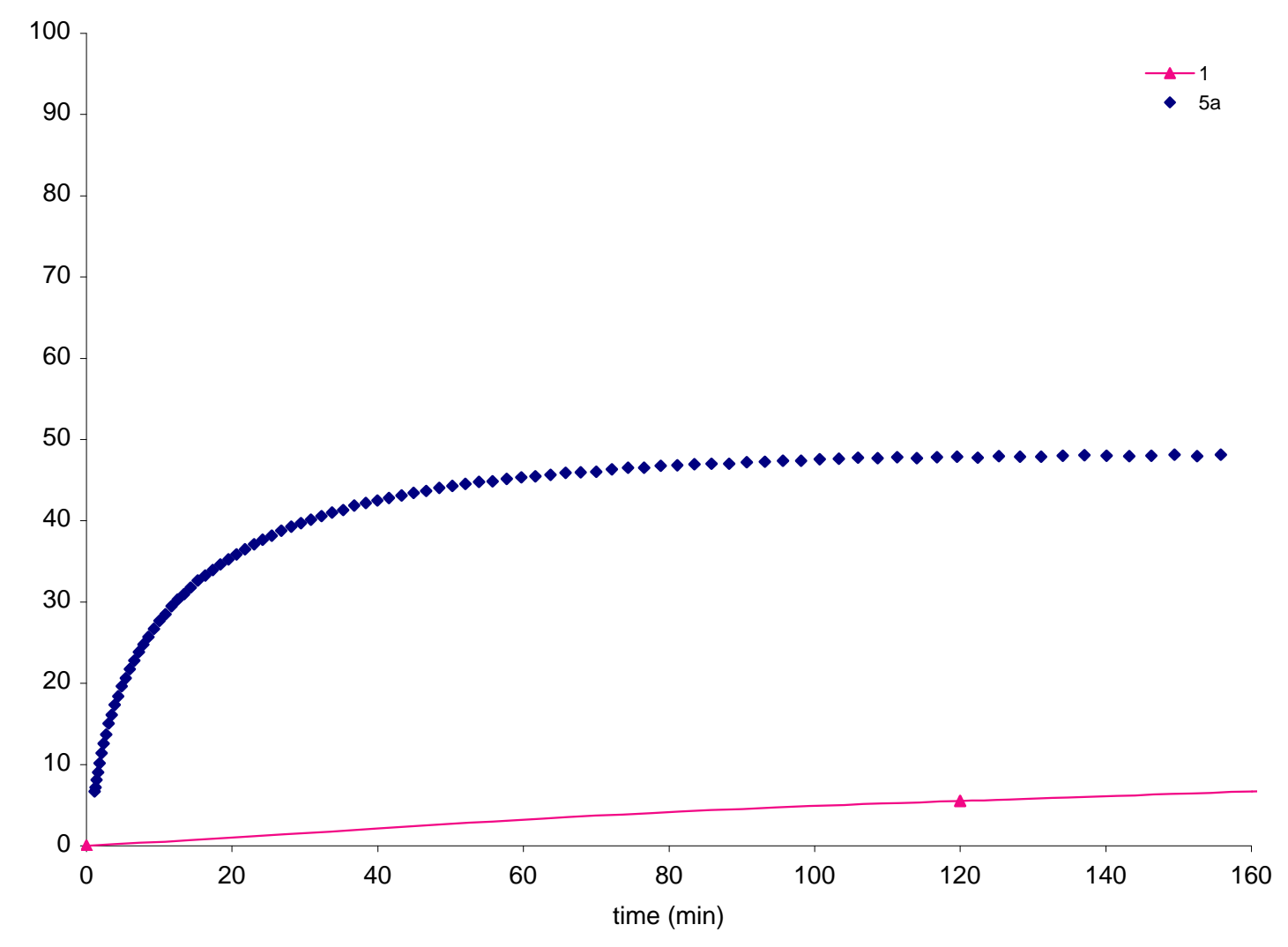


Figure S6. RCM of 9 using catalysts 4 and $6 a\left(5 \mathrm{~mol} \%, 30{ }^{\circ} \mathrm{C}, \mathrm{CD}_{2} \mathrm{Cl}_{2}\right)$.

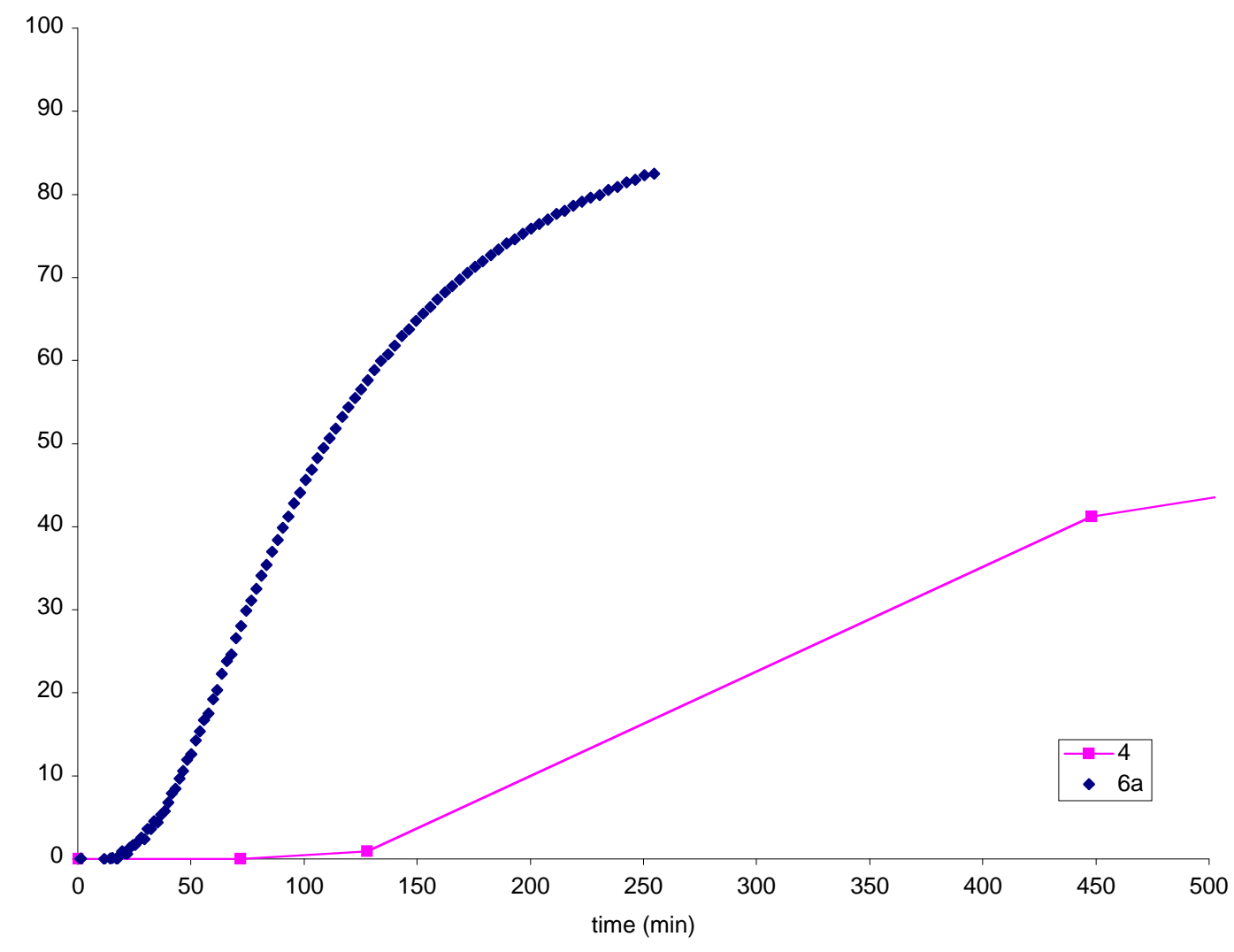


Figure S7. RCM of 9 using catalysts $6 a\left(2.5 \mathrm{~mol} \%, 60{ }^{\circ} \mathrm{C}, \mathrm{C}_{6} \mathrm{D}_{6}\right)$.

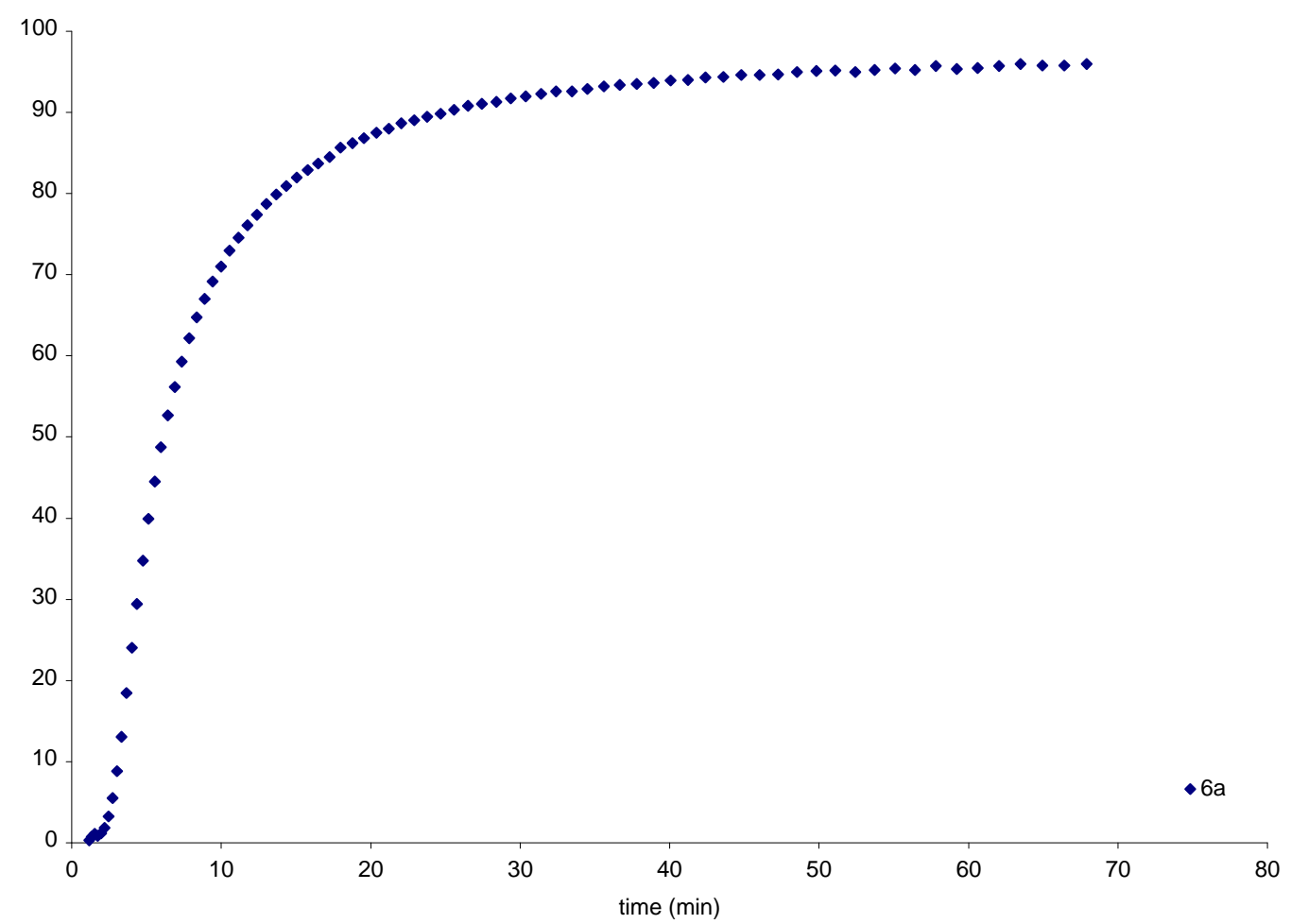




\section{GENERAL RCM PROCEDURE FOR TABLE $2{ }^{\text {iii }}$}

An NMR tube with a screw-cap septum top was charged inside a glovebox with catalyst stock solution (0.005 $\mathrm{M}$ in $\left.\mathrm{C}_{6} \mathrm{D}_{6}, 0.8 \mathrm{~mL}, 4.0 \mu \mathrm{mol}, 5.0 \mathrm{~mol} \%\right)$. The appropriate substrate (11-18, $0.080 \mathrm{mmol}, 0.1 \mathrm{M}$ ) was added via syringe and the sample placed in an oil bath regulated at 60 ${ }^{\circ} \mathrm{C}$. ${ }^{1} \mathrm{H}$ NMR spectra were taken at regular intervals. Conversion was determined by comparing the ratio of the integrals of the signals described below:

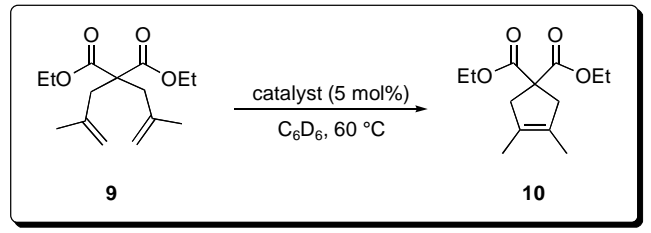

The SM methylene signal at 2.99 ppm was compared to the product signal at $3.14 \mathrm{ppm}$.

\section{ISOLATED YIELD FOR 10.}

In an argon-filled glove box, a $20 \mathrm{~mL}$ vial equipped with a stir bar was charged with 9 (472 mg, $1.76 \mathrm{mmol})$, toluene $(17.6 \mathrm{~mL})$, and catalyst 6a (50 mg, $0.088 \mathrm{mmol}, 5 \mathrm{~mol} \%$ ). The vial was then capped with a septum screw-cap, taken out of the glove box and heated to $60{ }^{\circ} \mathrm{C}$ for 1 hour while stirring and flushing the headspace with argon. The reaction mixture was treated to remove the catalyst: it was poured into a $2.0 \mathrm{M}$ solution of tris(hydroxymethyl)phosphine in isopropanol $(10 \mathrm{~mL})$ and this mixture heated to $60{ }^{\circ} \mathrm{C}$ for 1 hour. The colorless solution was diluted with water $(10 \mathrm{~mL})$ and the organic phase was extracted with diethyl ether $(2 \times 10 \mathrm{~mL})$, dried with magnesium sulfate, filtered and concentrated by rotary evaporation. The residue was purified by flash chromatography using hexanes as eluant before flushing the product with ethyl acetate. The fractions containing the product were combined and the volatiles were removed under vacuum to give 10 (422 $\mathrm{mg}, 1.75 \mathrm{mmol}, 100 \%$ yield). 


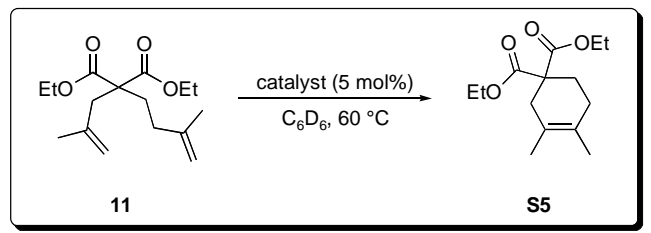

The SM methylene signal at $2.72 \mathrm{ppm}$ was compared to the product signal at $2.63 \mathrm{ppm}$.

\section{ISOLATED YIELD FOR S5.}

A $10 \mathrm{~mL}$ 2-neck round-bottom flask was outfitted with a reflux condensor and a septum, and flame-dried under vacuum. After cooling to r.t., 6a (5.1 mg, $0.009 \mathrm{mmol}, 5 \mathrm{~mol} \%)$ was added as a solid. Dry degassed benzene $(1.8 \mathrm{~mL})$ was added via syringe, followed by 11 (52 $\mu \mathrm{L}, 0.185$ mmol) via syringe. The septum was replaced with a ground-glass stopper, and the solution was stirred at $60{ }^{\circ} \mathrm{C}$ for $1 \mathrm{~h}$. The solution was cooled to r.t., and concentrated via rotary evaporation. Column chromatography ( $\mathrm{SiO}_{2}, 5 \%$ EtOAc:hexanes) afforded $\mathbf{S} 5$ as a colorless oil (47 mg, $0.185,100 \%)$.

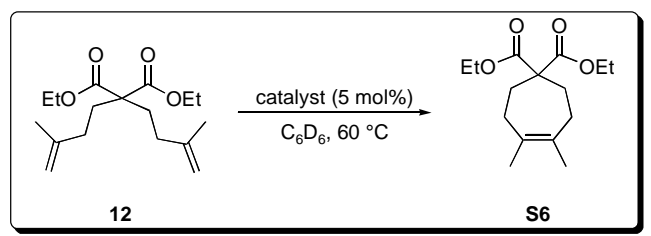

The SM methyl group signal at $1.59 \mathrm{ppm}$ was compared to the product signal at $1.50 \mathrm{ppm}$.

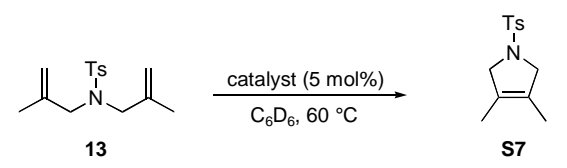

The SM methyl group signal at $3.62 \mathrm{ppm}$ was compared to the product signal at $3.84 \mathrm{ppm}$.

$$
\underbrace{}_{14} \frac{\text { catalyst }(5 \mathrm{~mol} \%)}{\mathrm{C}_{6} \mathrm{D}_{6}, 60^{\circ} \mathrm{C}} \longrightarrow
$$

The SM methylene signal at $3.68 \mathrm{ppm}$ was compared to the product signal at $4.45 \mathrm{ppm}$. 


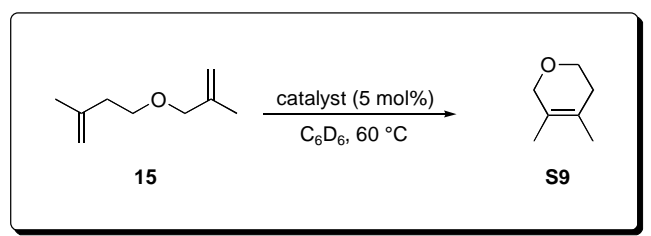

The SM methylene signal at $3.51 \mathrm{ppm}$ was compared to the product signal at $3.76 \mathrm{ppm}$. 


\section{X-RAY DIFFRACTION DATA FOR 6A}

Table S11. Crystal Data for $\mathbf{6 a}^{\mathrm{iv}}$

\begin{tabular}{|c|c|}
\hline Empirical formula & $\mathrm{C}_{27} \mathrm{H}_{30} \mathrm{~N}_{2} \mathrm{OCl}_{2} \mathrm{Ru}$ \\
\hline Formula weight & 570.50 \\
\hline Crystallization Solvent & Benzene/pentane \\
\hline Crystal Habit & Block \\
\hline Crystal size & $0.34 \times 0.28 \times 0.14 \mathrm{~mm}^{3}$ \\
\hline Crystal color & Dark green \\
\hline Type of diffractometer & Bruker SMART 1000 \\
\hline Wavelength & $0.71073 \AA \mathrm{MoK} \alpha$ \\
\hline Data Collection Temperature & $100(2) \mathrm{K}$ \\
\hline $\begin{array}{l}\theta \text { range for } 33816 \text { reflections used } \\
\text { in lattice determination }\end{array}$ & 2.34 to $41.57^{\circ}$ \\
\hline Unit cell dimensions & $\begin{array}{l}\mathrm{a}=11.5794(3) \AA \\
\mathrm{b}=13.9350(4) \AA \\
\mathrm{c}=16.6418(5) \AA\end{array}$ \\
\hline Volume & $2586.66(13) \AA^{3}$ \\
\hline $\mathrm{Z}$ & 4 \\
\hline Crystal system & Monoclinic \\
\hline Space group & $\mathrm{P} 2{ }_{1} / \mathrm{c}$ \\
\hline Density (calculated) & $1.465 \mathrm{Mg} / \mathrm{m}^{3}$ \\
\hline $\mathrm{F}(000)$ & 1168 \\
\hline$\theta$ range for data collection & 1.83 to $41.89^{\circ}$ \\
\hline Completeness to $\theta=41.89^{\circ}$ & $83.1 \%$ \\
\hline Index ranges & $-20 \leq \mathrm{h} \leq 20,-25 \leq \mathrm{k} \leq 25,-28 \leq 1 \leq 30$ \\
\hline Data collection scan type & $\omega$ scans at $7 \phi$ settings \\
\hline Reflections collected & 79070 \\
\hline Independent reflections & $14920\left[\mathrm{R}_{\mathrm{int}}=0.0822\right]$ \\
\hline Absorption coefficient & $0.835 \mathrm{~mm}^{-1}$ \\
\hline Absorption correction & None \\
\hline Max. and min. transmission & 0.8921 and 0.7645 \\
\hline
\end{tabular}

Table S12. Structure solution and refinement for $\mathbf{6 a}$

Structure solution program

Bruker XS v6.12

Primary solution method

Direct methods 
Secondary solution method

Hydrogen placement

Structure refinement program

Refinement method

Data / restraints / parameters

Treatment of hydrogen atoms

Goodness-of-fit on $\mathrm{F}^{2}$

Final R indices [I $>2 \sigma(\mathrm{I}), 10742$ reflections]

$\mathrm{R}$ indices (all data)

Type of weighting scheme used

Weighting scheme used

Max shift/error

Average shift/error

Largest diff. peak and hole
Difference Fourier map

Geometric positions

Bruker XL v6.12

Full matrix least-squares on $\mathrm{F}^{2}$

$14920 / 15 / 332$

Riding

1.350

$\mathrm{R} 1=0.0348, w \mathrm{R} 2=0.0652$

$\mathrm{R} 1=0.0575, w \mathrm{R} 2=0.0688$

Sigma

$w=1 / \sigma^{2}\left(\mathrm{Fo}^{2}\right)$

0.002

0.000

1.532 and -1.125 e. $\AA^{-3}$ 
Table S13. Atomic Coordinates for $\mathbf{6 a}$

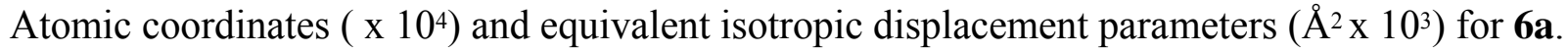
$\mathrm{U}(\mathrm{eq})$ is defined as the trace of the orthogonalized $\mathrm{U}^{\mathrm{ij}}$ tensor.

\begin{tabular}{|c|c|c|c|c|c|}
\hline & $\mathrm{x}$ & $\mathrm{y}$ & $\mathrm{z}$ & $\mathrm{U}_{\text {eq }}$ & Occ \\
\hline $\mathrm{Ru}(1)$ & $2308(1)$ & 7881(1) & $4144(1)$ & $13(1)$ & 1 \\
\hline $\mathrm{Cl}(1)$ & 4001(1) & 7354(1) & $5170(1)$ & $20(1)$ & 1 \\
\hline $\mathrm{Cl}(2)$ & $510(1)$ & $7840(1)$ & $3070(1)$ & 21(1) & 1 \\
\hline $\mathrm{O}(1)$ & $1253(1)$ & $7777(1)$ & $5129(1)$ & 19(1) & 1 \\
\hline $\mathrm{N}(1)$ & $3747(1)$ & $7208(1)$ & $3081(1)$ & 21(1) & 1 \\
\hline $\mathrm{N}(2)$ & $3374(1)$ & $8725(1)$ & $2819(1)$ & $18(1)$ & 1 \\
\hline$C(1)$ & $3211(1)$ & $7990(1)$ & $3305(1)$ & $15(1)$ & 1 \\
\hline$C(2)$ & $4111(2)$ & $7365(1)$ & $2308(1)$ & $30(1)$ & 1 \\
\hline$C(3)$ & $4132(1)$ & $8459(1)$ & $2266(1)$ & $26(1)$ & 1 \\
\hline$C(4)$ & $3626(1)$ & $6248(1)$ & $3360(1)$ & $24(1)$ & 1 \\
\hline$C(5)$ & $4658(2)$ & $5721(1)$ & $3737(1)$ & $31(1)$ & 1 \\
\hline$C(6)$ & $4494(2)$ & $4784(1)$ & $3986(1)$ & $40(1)$ & 1 \\
\hline$C(7)$ & $3367(2)$ & $4386(1)$ & $3866(1)$ & $42(1)$ & 1 \\
\hline $\mathrm{C}(8)$ & $2360(2)$ & 4917(1) & $3492(1)$ & $38(1)$ & 1 \\
\hline$C(9)$ & $2494(2)$ & $5858(1)$ & $3236(1)$ & $28(1)$ & 1 \\
\hline$C(10)$ & $5894(2)$ & 6144(1) & $3902(1)$ & $40(1)$ & 1 \\
\hline $\mathrm{C}(11)$ & $3010(2)$ & $9703(1)$ & $2852(1)$ & $16(1)$ & $0.914(2)$ \\
\hline$C(12)$ & $3802(1)$ & $10388(1)$ & $3313(1)$ & $18(1)$ & $0.914(2)$ \\
\hline$C(13)$ & $3374(1)$ & $11330(1)$ & $3324(1)$ & 21(1) & $0.914(2)$ \\
\hline$C(14)$ & $2222(2)$ & $11579(1)$ & $2878(1)$ & $23(1)$ & $0.914(2)$ \\
\hline$C(15)$ & $1456(1)$ & 10893(1) & $2413(1)$ & $22(1)$ & $0.914(2)$ \\
\hline$C(16)$ & 1851(1) & 9952(1) & $2406(1)$ & $20(1)$ & $0.914(2)$ \\
\hline$C(17)$ & $5050(2)$ & $10127(1)$ & $3804(1)$ & $27(1)$ & $0.914(2)$ \\
\hline$C(11 B)$ & $3366(10)$ & $9686(5)$ & $3060(9)$ & $15(4)$ & $0.086(2)$ \\
\hline$C(12 B)$ & $2437(7)$ & $10334(6)$ & $2723(6)$ & $14(2)$ & $0.086(2)$ \\
\hline$C(13 B)$ & $2553(8)$ & $11270(5)$ & $3047(7)$ & $12(2)$ & $0.086(2)$ \\
\hline$C(14 B)$ & $3558(9)$ & $11550(5)$ & $3665(7)$ & $14(3)$ & $0.086(2)$ \\
\hline$C(15 B)$ & $4470(8)$ & 10897(6) & 3991(6) & $15(3)$ & $0.086(2)$ \\
\hline$C(16 B)$ & 4394(7) & $9976(5)$ & $3659(6)$ & $8(2)$ & $0.086(2)$ \\
\hline$C(17 B)$ & $1349(10)$ & $10045(9)$ & $2048(9)$ & $31(4)$ & $0.086(2)$ \\
\hline $\mathrm{C}(18)$ & 2351(1) & $9129(1)$ & 4498(1) & $15(1)$ & 1 \\
\hline$C(19)$ & $1810(1)$ & $9379(1)$ & $5154(1)$ & $14(1)$ & 1 \\
\hline$C(20)$ & 1840(1) & 10317(1) & $5467(1)$ & $19(1)$ & 1 \\
\hline $\mathrm{C}(21)$ & $1284(1)$ & $10539(1)$ & $6085(1)$ & $22(1)$ & 1 \\
\hline $\mathrm{C}(22)$ & $697(1)$ & $9816(1)$ & $6398(1)$ & $23(1)$ & 1 \\
\hline$C(23)$ & $670(1)$ & 8871(1) & 6116(1) & 21(1) & 1 \\
\hline$C(24)$ & $1220(1)$ & $8662(1)$ & $5490(1)$ & $16(1)$ & 1 \\
\hline$C(25)$ & $679(1)$ & 6957(1) & 5418(1) & $23(1)$ & 1 \\
\hline$C(26)$ & $1224(2)$ & 6064(1) & $5147(1)$ & $30(1)$ & 1 \\
\hline$C(27)$ & $-670(1)$ & $7000(1)$ & $5046(1)$ & $33(1)$ & 1 \\
\hline
\end{tabular}


Table S14. Selected bond lengths $[\AA]$ and angles $\left[{ }^{\circ}\right]$ for $\mathbf{6 a}$

\begin{tabular}{lclr}
\hline $\mathrm{Ru}(1)-\mathrm{C}(18)$ & $1.8329(11)$ & $\mathrm{C}(18)-\mathrm{Ru}(1)-\mathrm{C}(1)$ & $100.45(5)$ \\
$\mathrm{Ru}(1)-\mathrm{C}(1)$ & $1.9611(11)$ & $\mathrm{C}(18)-\mathrm{Ru}(1)-\mathrm{O}(1)$ & $78.71(4)$ \\
$\mathrm{Ru}(1)-\mathrm{O}(1)$ & $2.2979(8)$ & $\mathrm{C}(1)-\mathrm{Ru}(1)-\mathrm{O}(1)$ & $179.15(4)$ \\
$\mathrm{Ru}(1)-\mathrm{Cl}(1)$ & $2.3445(3)$ & $\mathrm{C}(18)-\mathrm{Ru}(1)-\mathrm{Cl}(1)$ & $96.76(4)$ \\
$\mathrm{Ru}(1)-\mathrm{Cl}(2)$ & $2.3523(3)$ & $\mathrm{C}(1)-\mathrm{Ru}(1)-\mathrm{Cl}(1)$ & $92.38(4)$ \\
& & $\mathrm{O}(1)-\mathrm{Ru}(1)-\mathrm{Cl}(1)$ & $87.76(3)$ \\
& & $\mathrm{C}(18)-\mathrm{Ru}(1)-\mathrm{Cl}(2)$ & $102.05(4)$ \\
& & $\mathrm{C}(1)-\operatorname{Ru}(1)-\mathrm{Cl}(2)$ & $89.65(4)$ \\
& & $\mathrm{O}(1)-\operatorname{Ru}(1)-\mathrm{Cl}(2)$ & $90.49(3)$ \\
& & $\mathrm{Cl}(1)-\operatorname{Ru}(1)-\mathrm{Cl}(2)$ & $160.382(12)$ \\
\hline
\end{tabular}

Table S15. Bond lengths $[\AA]$ and angles $\left[^{\circ}\right]$ for $\mathbf{6 a}$

\begin{tabular}{lclc}
\hline $\mathrm{Ru}(1)-\mathrm{C}(18)$ & $1.8329(11)$ & $\mathrm{C}(12 \mathrm{~B})-\mathrm{C}(17 \mathrm{~B})$ & $1.501(2)$ \\
$\mathrm{Ru}(1)-\mathrm{C}(1)$ & $1.9611(11)$ & $\mathrm{C}(13 \mathrm{~B})-\mathrm{C}(14 \mathrm{~B})$ & $1.386(2)$ \\
$\mathrm{Ru}(1)-\mathrm{O}(1)$ & $2.2979(8)$ & $\mathrm{C}(14 \mathrm{~B})-\mathrm{C}(15 \mathrm{~B})$ & $1.389(2)$ \\
$\mathrm{Ru}(1)-\mathrm{Cl}(1)$ & $2.3445(3)$ & $\mathrm{C}(15 \mathrm{~B})-\mathrm{C}(16 \mathrm{~B})$ & $1.390(2)$ \\
$\mathrm{Ru}(1)-\mathrm{Cl}(2)$ & $2.3523(3)$ & $\mathrm{C}(18)-\mathrm{C}(19)$ & $1.4404(15)$ \\
$\mathrm{O}(1)-\mathrm{C}(24)$ & $1.3766(14)$ & $\mathrm{C}(19)-\mathrm{C}(20)$ & $1.4042(16)$ \\
$\mathrm{O}(1)-\mathrm{C}(25)$ & $1.4664(14)$ & $\mathrm{C}(19)-\mathrm{C}(24)$ & $1.4074(16)$ \\
$\mathrm{N}(1)-\mathrm{C}(1)$ & $1.3550(14)$ & $\mathrm{C}(20)-\mathrm{C}(21)$ & $1.3869(17)$ \\
$\mathrm{N}(1)-\mathrm{C}(4)$ & $1.4352(16)$ & $\mathrm{C}(21)-\mathrm{C}(22)$ & $1.392(2)$ \\
$\mathrm{N}(1)-\mathrm{C}(2)$ & $1.4742(16)$ & $\mathrm{C}(22)-\mathrm{C}(23)$ & $1.3952(18)$ \\
$\mathrm{N}(2)-\mathrm{C}(1)$ & $1.3503(15)$ & $\mathrm{C}(23)-\mathrm{C}(24)$ & $1.3912(16)$ \\
$\mathrm{N}(2)-\mathrm{C}(11 \mathrm{~B})$ & $1.399(6)$ & $\mathrm{C}(25)-\mathrm{C}(26)$ & $1.5167(19)$ \\
$\mathrm{N}(2)-\mathrm{C}(11)$ & $1.4316(16)$ & $\mathrm{C}(25)-\mathrm{C}(27)$ & $1.519(2)$ \\
$\mathrm{N}(2)-\mathrm{C}(3)$ & $1.4794(15)$ & & \\
$\mathrm{C}(2)-\mathrm{C}(3)$ & $1.526(2)$ & $\mathrm{C}(18)-\mathrm{Ru}(1)-\mathrm{C}(1)$ & $100.45(5)$ \\
$\mathrm{C}(4)-\mathrm{C}(9)$ & $1.383(2)$ & $\mathrm{C}(18)-\mathrm{Ru}(1)-\mathrm{O}(1)$ & $78.71(4)$ \\
$\mathrm{C}(4)-\mathrm{C}(5)$ & $1.400(2)$ & $\mathrm{C}(1)-\mathrm{Ru}(1)-\mathrm{O}(1)$ & $179.15(4)$ \\
$\mathrm{C}(5)-\mathrm{C}(6)$ & $1.397(2)$ & $\mathrm{C}(18)-\mathrm{Ru}(1)-\mathrm{Cl}(1)$ & $96.76(4)$ \\
$\mathrm{C}(5)-\mathrm{C}(10)$ & $1.503(3)$ & $\mathrm{C}(1)-\mathrm{Ru}(1)-\mathrm{Cl}(1)$ & $92.38(4)$ \\
$\mathrm{C}(6)-\mathrm{C}(7)$ & $1.382(3)$ & $\mathrm{O}(1)-\mathrm{Ru}(1)-\mathrm{Cl}(1)$ & $87.76(3)$ \\
$\mathrm{C}(7)-\mathrm{C}(8)$ & $1.381(3)$ & $\mathrm{C}(18)-\mathrm{Ru}(1)-\mathrm{Cl}(2)$ & $102.05(4)$ \\
$\mathrm{C}(8)-\mathrm{C}(9)$ & $1.400(2)$ & $\mathrm{C}(1)-\mathrm{Ru}(1)-\mathrm{Cl}(2)$ & $89.65(4)$ \\
$\mathrm{C}(11)-\mathrm{C}(16)$ & $1.392(2)$ & $\mathrm{O}(1)-\mathrm{Ru}(1)-\mathrm{Cl}(2)$ & $90.49(3)$ \\
$\mathrm{C}(11)-\mathrm{C}(12)$ & $1.402(2)$ & $\mathrm{Cl}(1)-\mathrm{Ru}(1)-\mathrm{Cl}(2)$ & $160.382(12)$ \\
$\mathrm{C}(12)-\mathrm{C}(13)$ & $1.4038(19)$ & $\mathrm{C}(24)-\mathrm{O}(1)-\mathrm{C}(25)$ & $119.21(9)$ \\
$\mathrm{C}(12)-\mathrm{C}(17)$ & $1.501(2)$ & $\mathrm{C}(24)-\mathrm{O}(1)-\mathrm{Ru}(1)$ & $109.69(7)$ \\
$\mathrm{C}(13)-\mathrm{C}(14)$ & $1.386(2)$ & $\mathrm{C}(25)-\mathrm{O}(1)-\mathrm{Ru}(1)$ & $131.09(7)$ \\
$\mathrm{C}(14)-\mathrm{C}(15)$ & $1.389(2)$ & $\mathrm{C}(1)-\mathrm{N}(1)-\mathrm{C}(4)$ & $124.61(10)$ \\
$\mathrm{C}(15)-\mathrm{C}(16)$ & $1.3902(19)$ & $\mathrm{C}(1)-\mathrm{N}(1)-\mathrm{C}(2)$ & $112.39(10)$ \\
$\mathrm{C}(11 \mathrm{~B})-\mathrm{C}(16 \mathrm{~B})$ & $1.392(3)$ & $\mathrm{C}(4)-\mathrm{N}(1)-\mathrm{C}(2)$ & $119.80(10)$ \\
$\mathrm{C}(11 \mathrm{~B})-\mathrm{C}(12 \mathrm{~B})$ & $1.402(2)$ & $\mathrm{C}(1)-\mathrm{N}(2)-\mathrm{C}(11 \mathrm{~B})$ & $122.8(7)$ \\
$\mathrm{C}(12 \mathrm{~B})-\mathrm{C}(13 \mathrm{~B})$ & $1.404(2)$ & $\mathrm{C}(1)-\mathrm{N}(2)-\mathrm{C}(11)$ & $127.49(10)$
\end{tabular}




\begin{tabular}{|c|c|c|c|}
\hline $\mathrm{C}(11 \mathrm{~B})-\mathrm{N}(2)-\mathrm{C}(11)$ & $18.8(3)$ & $C(14)-C(15)-C(16)$ & $119.42(14)$ \\
\hline $\mathrm{C}(1)-\mathrm{N}(2)-\mathrm{C}(3)$ & $112.63(10)$ & $C(15)-C(16)-C(11)$ & $120.24(14)$ \\
\hline $\mathrm{C}(11 \mathrm{~B})-\mathrm{N}(2)-\mathrm{C}(3)$ & $118.0(8)$ & $\mathrm{C}(16 \mathrm{~B})-\mathrm{C}(11 \mathrm{~B})-\mathrm{N}(2)$ & $114.4(5)$ \\
\hline $\mathrm{C}(11)-\mathrm{N}(2)-\mathrm{C}(3)$ & $119.52(10)$ & $\mathrm{C}(16 \mathrm{~B})-\mathrm{C}(11 \mathrm{~B})-\mathrm{C}(12 \mathrm{~B})$ & $121.08(18)$ \\
\hline $\mathrm{N}(2)-\mathrm{C}(1)-\mathrm{N}(1)$ & $107.24(10)$ & $\mathrm{N}(2)-\mathrm{C}(11 \mathrm{~B})-\mathrm{C}(12 \mathrm{~B})$ & $124.4(5)$ \\
\hline $\mathrm{N}(2)-\mathrm{C}(1)-\mathrm{Ru}(1)$ & $132.26(8)$ & $\mathrm{C}(11 \mathrm{~B})-\mathrm{C}(12 \mathrm{~B})-\mathrm{C}(13 \mathrm{~B})$ & $117.48(18)$ \\
\hline $\mathrm{N}(1)-\mathrm{C}(1)-\mathrm{Ru}(1)$ & $120.34(8)$ & $\mathrm{C}(11 \mathrm{~B})-\mathrm{C}(12 \mathrm{~B})-\mathrm{C}(17 \mathrm{~B})$ & $121.73(19)$ \\
\hline $\mathrm{N}(1)-\mathrm{C}(2)-\mathrm{C}(3)$ & $101.52(10)$ & $\mathrm{C}(13 \mathrm{~B})-\mathrm{C}(12 \mathrm{~B})-\mathrm{C}(17 \mathrm{~B})$ & $120.79(19)$ \\
\hline $\mathrm{N}(2)-\mathrm{C}(3)-\mathrm{C}(2)$ & $101.69(10)$ & $\mathrm{C}(14 \mathrm{~B})-\mathrm{C}(13 \mathrm{~B})-\mathrm{C}(12 \mathrm{~B})$ & $121.37(18)$ \\
\hline$C(9)-C(4)-C(5)$ & $121.43(13)$ & $\mathrm{C}(13 \mathrm{~B})-\mathrm{C}(14 \mathrm{~B})-\mathrm{C}(15 \mathrm{~B})$ & $120.29(18)$ \\
\hline$C(9)-C(4)-N(1)$ & $119.31(12)$ & $\mathrm{C}(14 \mathrm{~B})-\mathrm{C}(15 \mathrm{~B})-\mathrm{C}(16 \mathrm{~B})$ & $119.32(19)$ \\
\hline $\mathrm{C}(5)-\mathrm{C}(4)-\mathrm{N}(1)$ & $119.25(14)$ & $\mathrm{C}(15 \mathrm{~B})-\mathrm{C}(16 \mathrm{~B})-\mathrm{C}(11 \mathrm{~B})$ & $120.2(2)$ \\
\hline$C(6)-C(5)-C(4)$ & $117.10(17)$ & $\mathrm{C}(19)-\mathrm{C}(18)-\mathrm{Ru}(1)$ & $119.54(8)$ \\
\hline$C(6)-C(5)-C(10)$ & $120.72(15)$ & $\mathrm{C}(20)-\mathrm{C}(19)-\mathrm{C}(24)$ & $118.62(10)$ \\
\hline$C(4)-C(5)-C(10)$ & $122.14(14)$ & $\mathrm{C}(20)-\mathrm{C}(19)-\mathrm{C}(18)$ & $122.29(11)$ \\
\hline$C(7)-C(6)-C(5)$ & $122.04(16)$ & $\mathrm{C}(24)-\mathrm{C}(19)-\mathrm{C}(18)$ & $119.08(10)$ \\
\hline$C(8)-C(7)-C(6)$ & $120.02(15)$ & $\mathrm{C}(21)-\mathrm{C}(20)-\mathrm{C}(19)$ & $120.87(12)$ \\
\hline$C(7)-C(8)-C(9)$ & $119.32(18)$ & $\mathrm{C}(20)-\mathrm{C}(21)-\mathrm{C}(22)$ & $119.09(12)$ \\
\hline $\mathrm{C}(4)-\mathrm{C}(9)-\mathrm{C}(8)$ & $120.10(15)$ & $\mathrm{C}(21)-\mathrm{C}(22)-\mathrm{C}(23)$ & $121.77(11)$ \\
\hline$C(16)-C(11)-C(12)$ & $121.15(12)$ & $\mathrm{C}(24)-\mathrm{C}(23)-\mathrm{C}(22)$ & $118.40(12)$ \\
\hline $\mathrm{C}(16)-\mathrm{C}(11)-\mathrm{N}(2)$ & $117.96(13)$ & $\mathrm{O}(1)-\mathrm{C}(24)-\mathrm{C}(23)$ & $125.86(11)$ \\
\hline $\mathrm{C}(12)-\mathrm{C}(11)-\mathrm{N}(2)$ & $120.89(15)$ & $\mathrm{O}(1)-\mathrm{C}(24)-\mathrm{C}(19)$ & 112.93(9) \\
\hline C(11)-C(12)-C(13) & $117.54(14)$ & $\mathrm{C}(23)-\mathrm{C}(24)-\mathrm{C}(19)$ & $121.21(11)$ \\
\hline C(11)-C(12)-C(17) & $121.70(13)$ & $\mathrm{O}(1)-\mathrm{C}(25)-\mathrm{C}(26)$ & $106.31(10)$ \\
\hline C(13)-C(12)-C(17) & $120.73(14)$ & $\mathrm{O}(1)-\mathrm{C}(25)-\mathrm{C}(27)$ & $110.04(11)$ \\
\hline $\mathrm{C}(14)-\mathrm{C}(13)-\mathrm{C}(12)$ & $121.32(14)$ & $\mathrm{C}(26)-\mathrm{C}(25)-\mathrm{C}(27)$ & $112.08(13)$ \\
\hline C(13)-C(14)-C(15) & $120.31(13)$ & & \\
\hline
\end{tabular}


Table S16. Anisotropic displacement parameters $\left(\AA^{2} \times 10^{4}\right)$ for $6 \mathbf{a}$

The anisotropic displacement factor exponent takes the form:

$$
-2 \pi^{2}\left[h^{2} a^{* 2} U^{11}+\ldots+2 h k a^{*} b^{*} U^{12}\right]
$$

\begin{tabular}{llllrrr}
\hline & $\mathrm{U}^{11}$ & $\mathrm{U}^{22}$ & $\mathrm{U}^{33}$ & \multicolumn{1}{c}{$\mathrm{U}^{23}$} & \multicolumn{1}{c}{$\mathrm{U}^{13}$} & $\mathrm{U}^{12}$ \\
\hline $\mathrm{Ru}(1)$ & $167(1)$ & $116(1)$ & $121(1)$ & $0(1)$ & $60(1)$ & $17(1)$ \\
$\mathrm{Cl}(1)$ & $254(2)$ & $225(1)$ & $131(1)$ & $30(1)$ & $55(1)$ & $80(1)$ \\
$\mathrm{Cl}(2)$ & $185(1)$ & $205(1)$ & $218(1)$ & $-50(1)$ & $26(1)$ & $5(1)$ \\
$\mathrm{O}(1)$ & $250(5)$ & $147(4)$ & $205(4)$ & $-14(3)$ & $129(4)$ & $-27(3)$ \\
$\mathrm{N}(1)$ & $341(6)$ & $188(4)$ & $149(5)$ & $31(4)$ & $136(4)$ & $115(4)$ \\
$\mathrm{N}(2)$ & $239(6)$ & $168(4)$ & $164(5)$ & $26(4)$ & $123(4)$ & $52(4)$ \\
$\mathrm{C}(1)$ & $165(5)$ & $155(5)$ & $116(5)$ & $11(4)$ & $32(4)$ & $42(4)$ \\
$\mathrm{C}(2)$ & $483(10)$ & $270(6)$ & $216(7)$ & $51(5)$ & $220(7)$ & $162(6)$ \\
$\mathrm{C}(3)$ & $347(8)$ & $272(6)$ & $226(6)$ & $33(5)$ & $201(6)$ & $75(6)$ \\
$\mathrm{C}(4)$ & $426(8)$ & $186(5)$ & $123(5)$ & $21(4)$ & $113(5)$ & $146(6)$ \\
$\mathrm{C}(5)$ & $498(10)$ & $301(7)$ & $146(6)$ & $44(5)$ & $128(6)$ & $232(7)$ \\
$\mathrm{C}(6)$ & $749(13)$ & $286(7)$ & $191(7)$ & $75(6)$ & $184(8)$ & $319(8)$ \\
$\mathrm{C}(7)$ & $882(15)$ & $184(6)$ & $225(7)$ & $42(5)$ & $191(9)$ & $129(8)$ \\
$\mathrm{C}(8)$ & $682(13)$ & $206(6)$ & $263(8)$ & $-1(6)$ & $131(8)$ & $1(7)$ \\
$\mathrm{C}(9)$ & $473(9)$ & $181(5)$ & $191(6)$ & $8(5)$ & $86(6)$ & $80(6)$ \\
$\mathrm{C}(10)$ & $416(10)$ & $569(11)$ & $260(8)$ & $102(7)$ & $149(7)$ & $271(9)$ \\
$\mathrm{C}(11)$ & $210(9)$ & $159(6)$ & $142(7)$ & $19(4)$ & $96(6)$ & $8(5)$ \\
$\mathrm{C}(12)$ & $179(7)$ & $209(6)$ & $181(6)$ & $27(5)$ & $77(5)$ & $-6(5)$ \\
$\mathrm{C}(13)$ & $238(8)$ & $188(6)$ & $228(7)$ & $4(5)$ & $103(6)$ & $-35(5)$ \\
$\mathrm{C}(14)$ & $261(8)$ & $174(6)$ & $288(8)$ & $16(5)$ & $128(6)$ & $26(6)$ \\
$\mathrm{C}(15)$ & $192(7)$ & $219(6)$ & $254(7)$ & $28(5)$ & $53(6)$ & $47(5)$ \\
$\mathrm{C}(16)$ & $210(7)$ & $196(6)$ & $186(6)$ & $6(5)$ & $68(5)$ & $8(5)$ \\
$\mathrm{C}(17)$ & $216(8)$ & $295(7)$ & $268(8)$ & $27(6)$ & $14(6)$ & $6(6)$ \\
$\mathrm{C}(18)$ & $186(6)$ & $149(4)$ & $146(5)$ & $-7(4)$ & $76(4)$ & $-12(4)$ \\
$\mathrm{C}(19)$ & $158(6)$ & $150(4)$ & $132(5)$ & $-4(4)$ & $49(4)$ & $18(4)$ \\
$\mathrm{C}(20)$ & $222(6)$ & $156(5)$ & $184(6)$ & $-18(4)$ & $62(5)$ & $16(5)$ \\
$\mathrm{C}(21)$ & $275(7)$ & $212(5)$ & $193(6)$ & $-49(5)$ & $78(5)$ & $47(5)$ \\
$\mathrm{C}(22)$ & $237(7)$ & $295(6)$ & $176(6)$ & $-30(5)$ & $91(5)$ & $63(5)$ \\
$\mathrm{C}(23)$ & $214(6)$ & $255(6)$ & $188(6)$ & $-7(5)$ & $108(5)$ & $5(5)$ \\
$\mathrm{C}(24)$ & $155(6)$ & $171(5)$ & $147(5)$ & $-6(4)$ & $52(4)$ & $10(4)$ \\
$\mathrm{C}(25)$ & $278(7)$ & $187(5)$ & $261(6)$ & $22(5)$ & $128(5)$ & $-48(5)$ \\
$\mathrm{C}(26)$ & $381(9)$ & $162(5)$ & $406(9)$ & $-3(6)$ & $171(7)$ & $-41(6)$ \\
$\mathrm{C}(27)$ & $286(8)$ & $301(7)$ & $419(9)$ & $-15(6)$ & $148(7)$ & $-82(6)$ \\
\hline & & & & & & \\
\end{tabular}


Figure S8. ORTEP drawing of syn-6a

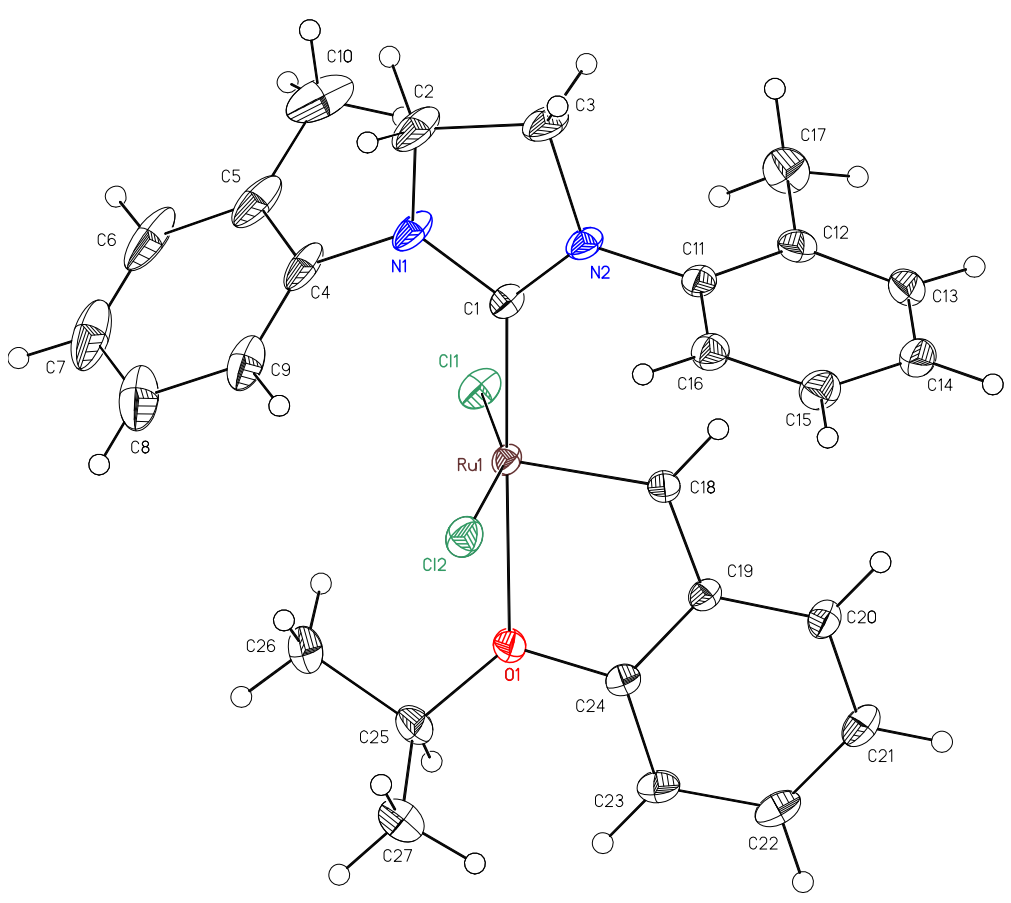

Figure S9. ORTEP drawing of anti-6a

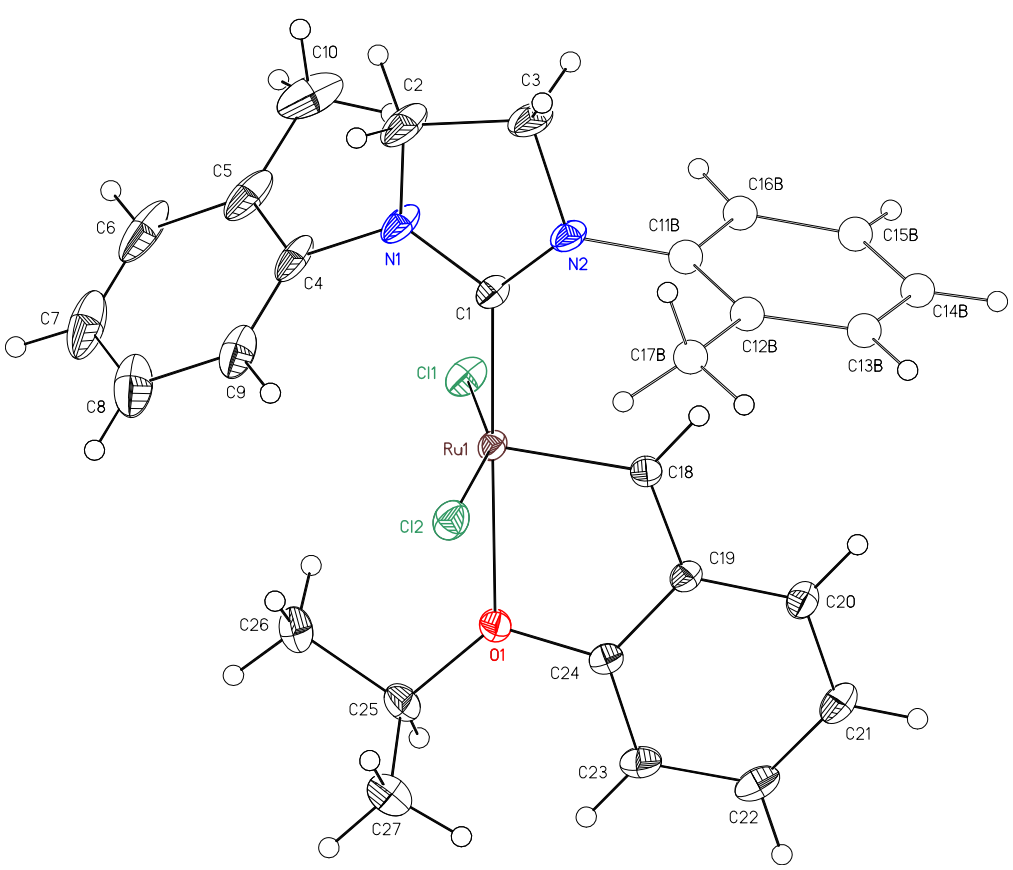


Figure S10. ORTEP drawing of superimposed syn- and anti-6a

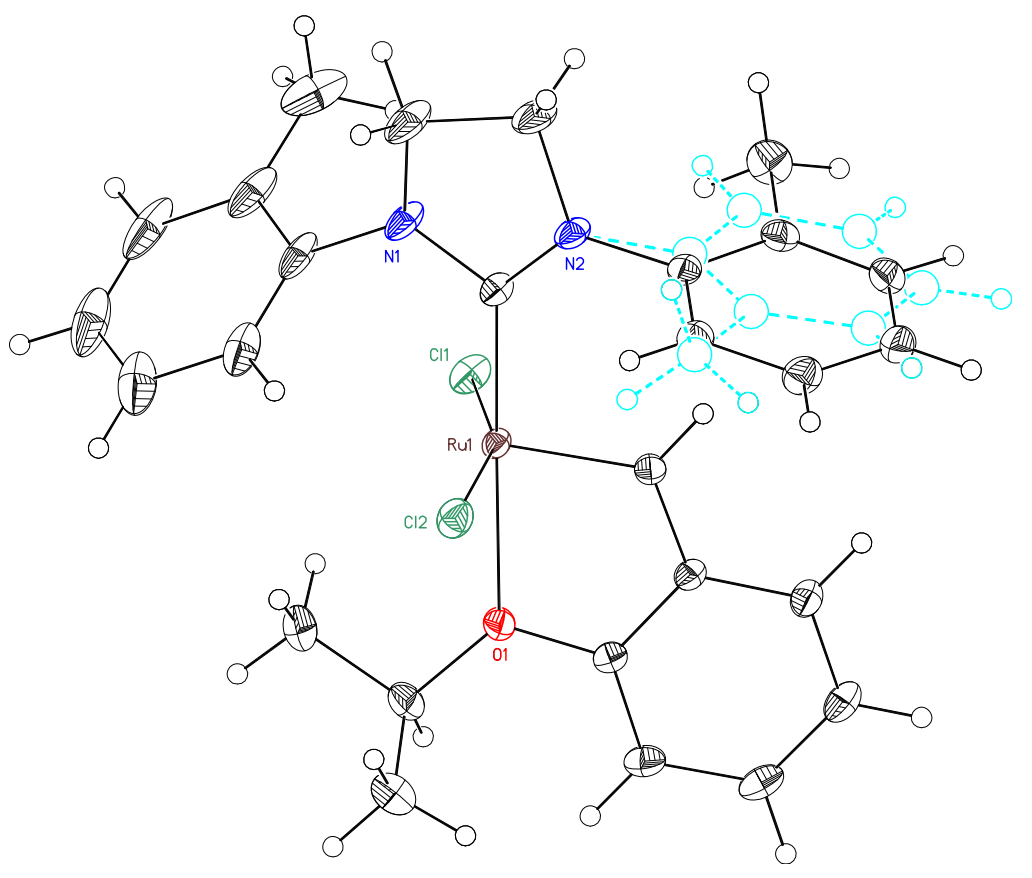




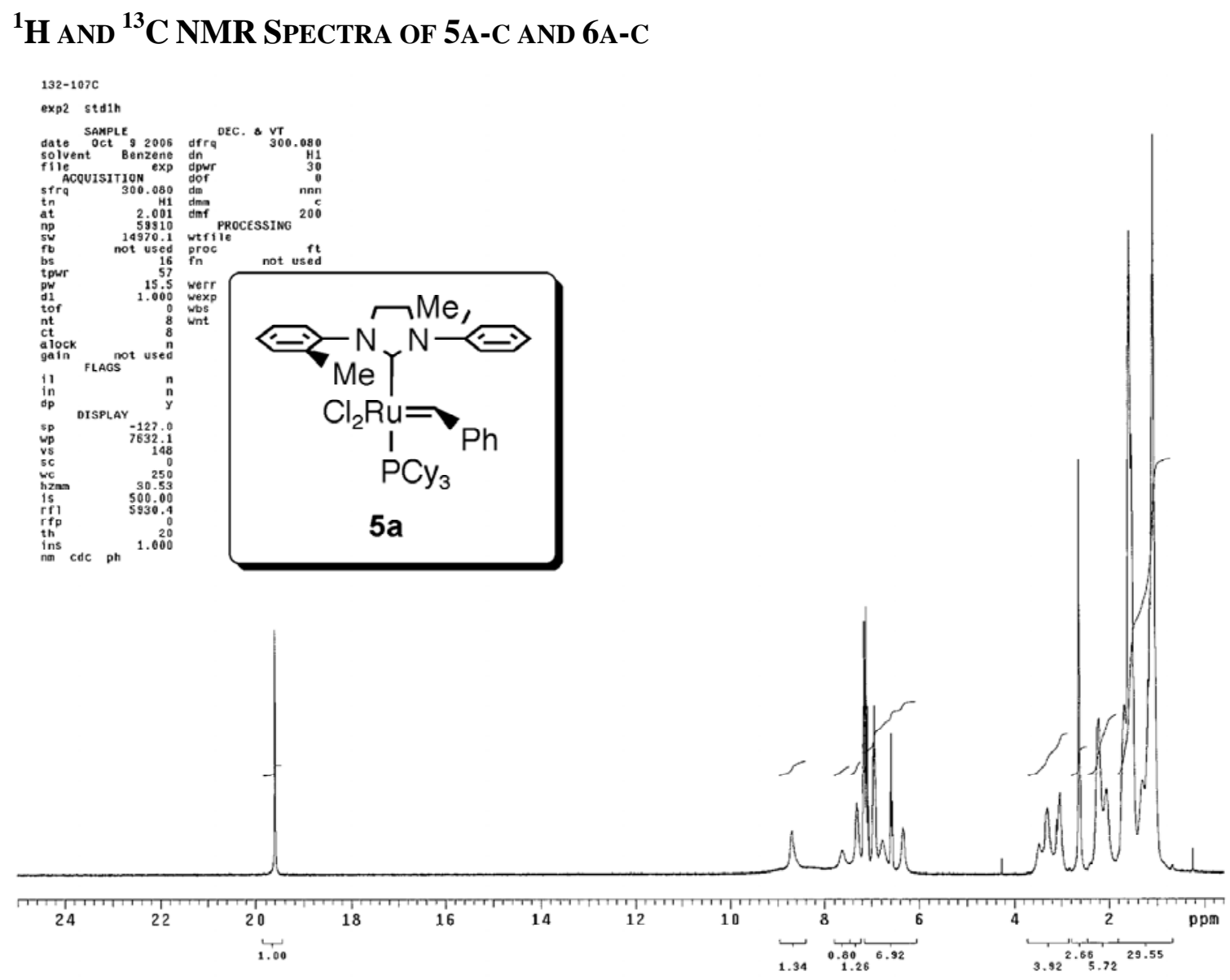




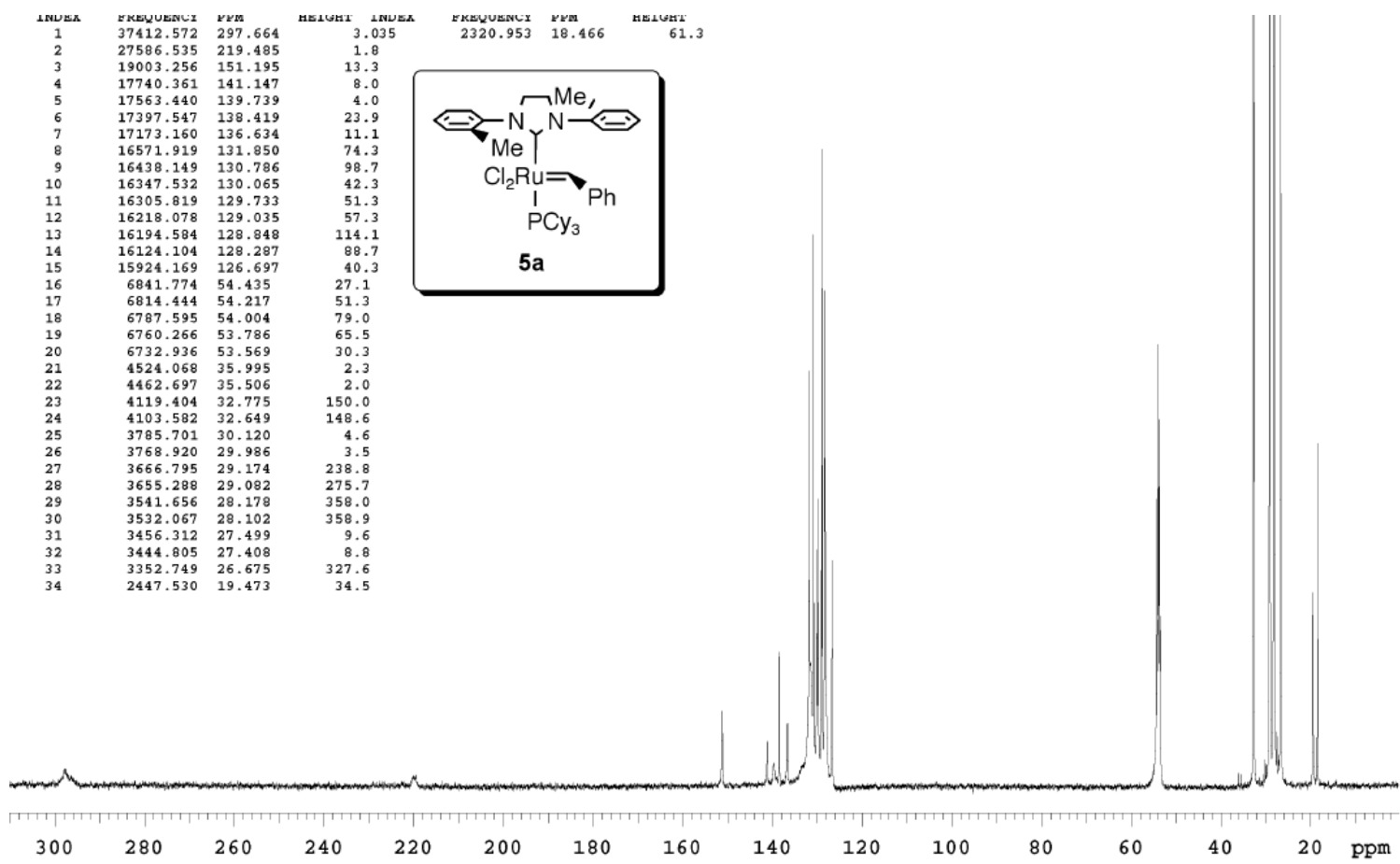




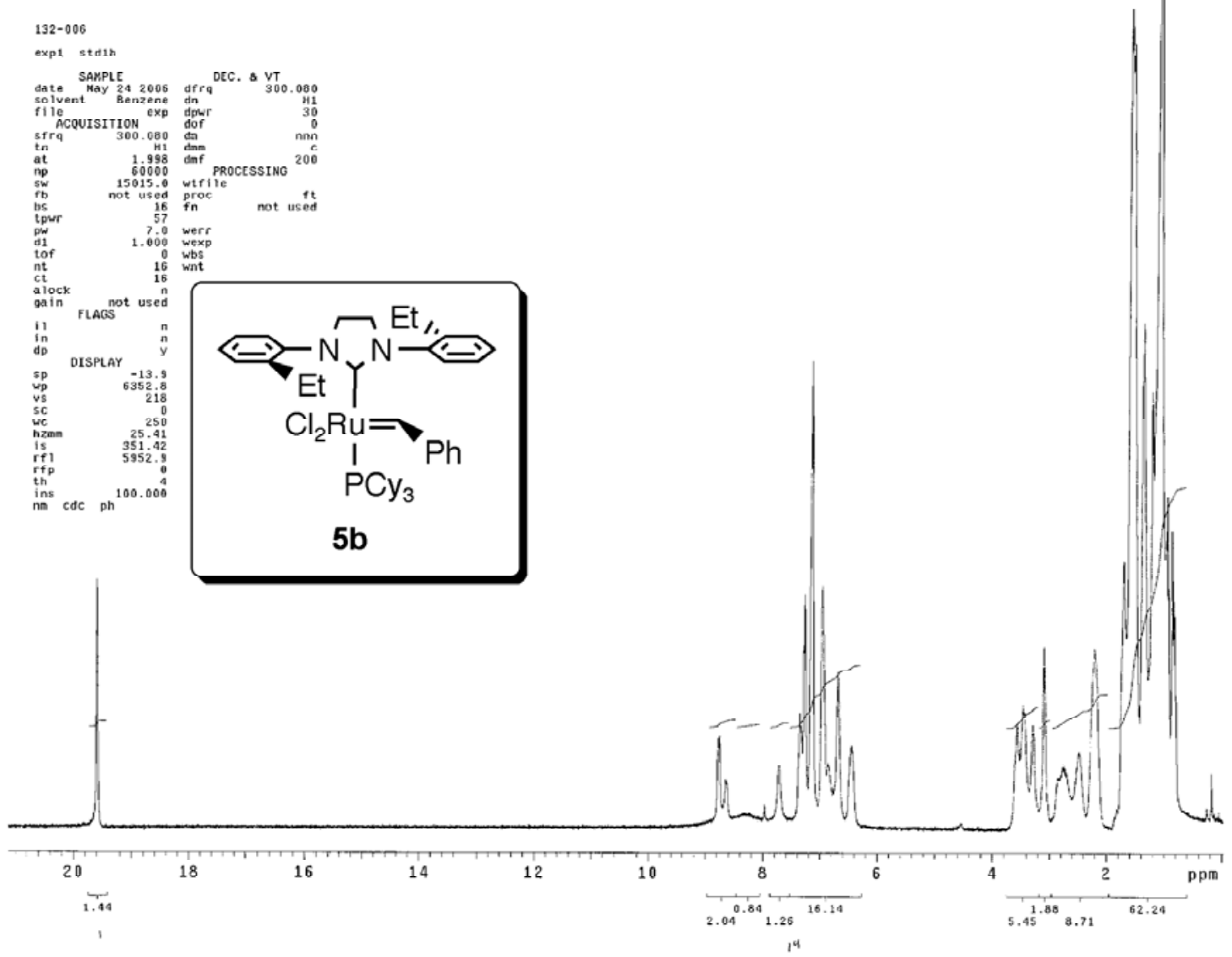




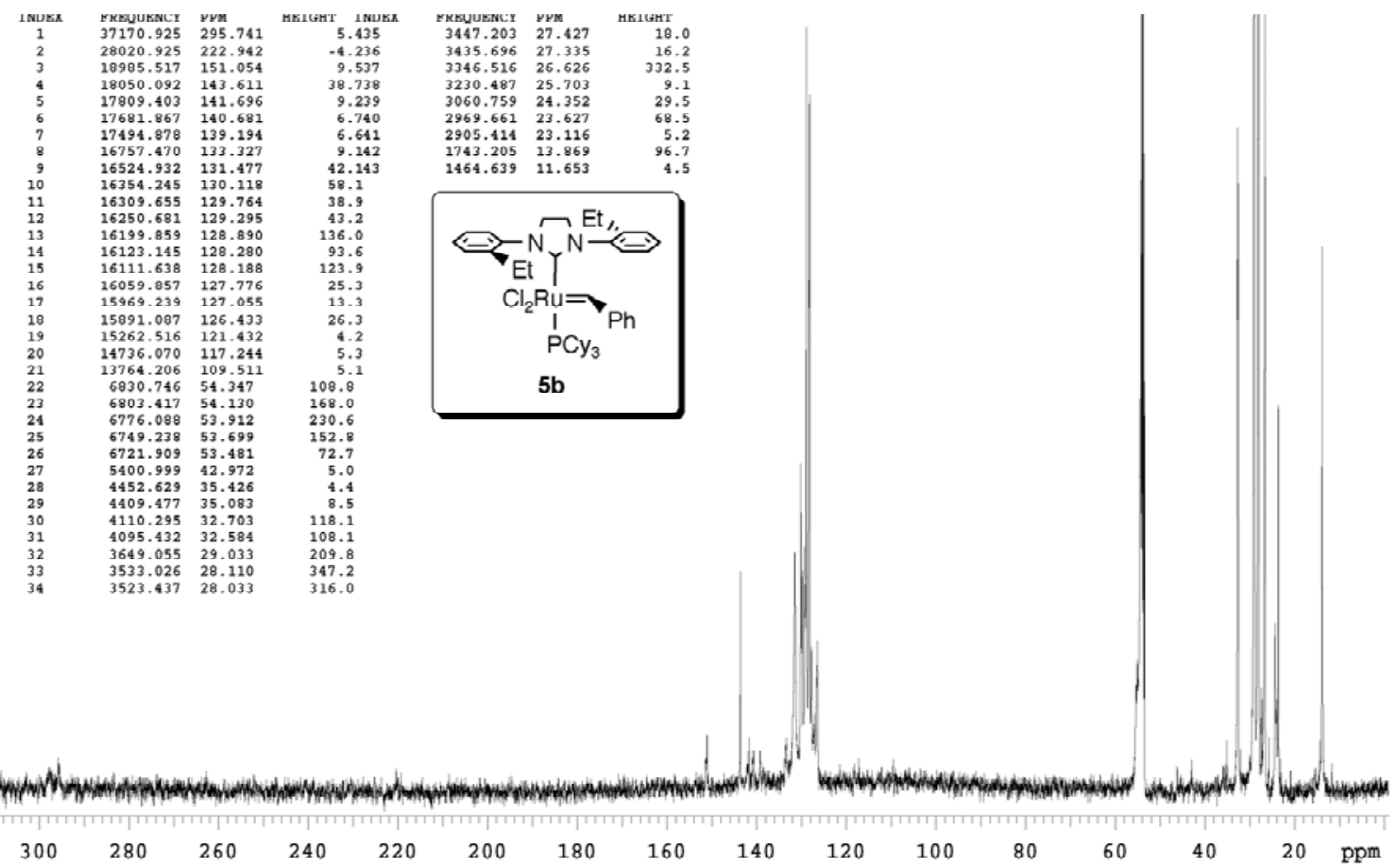



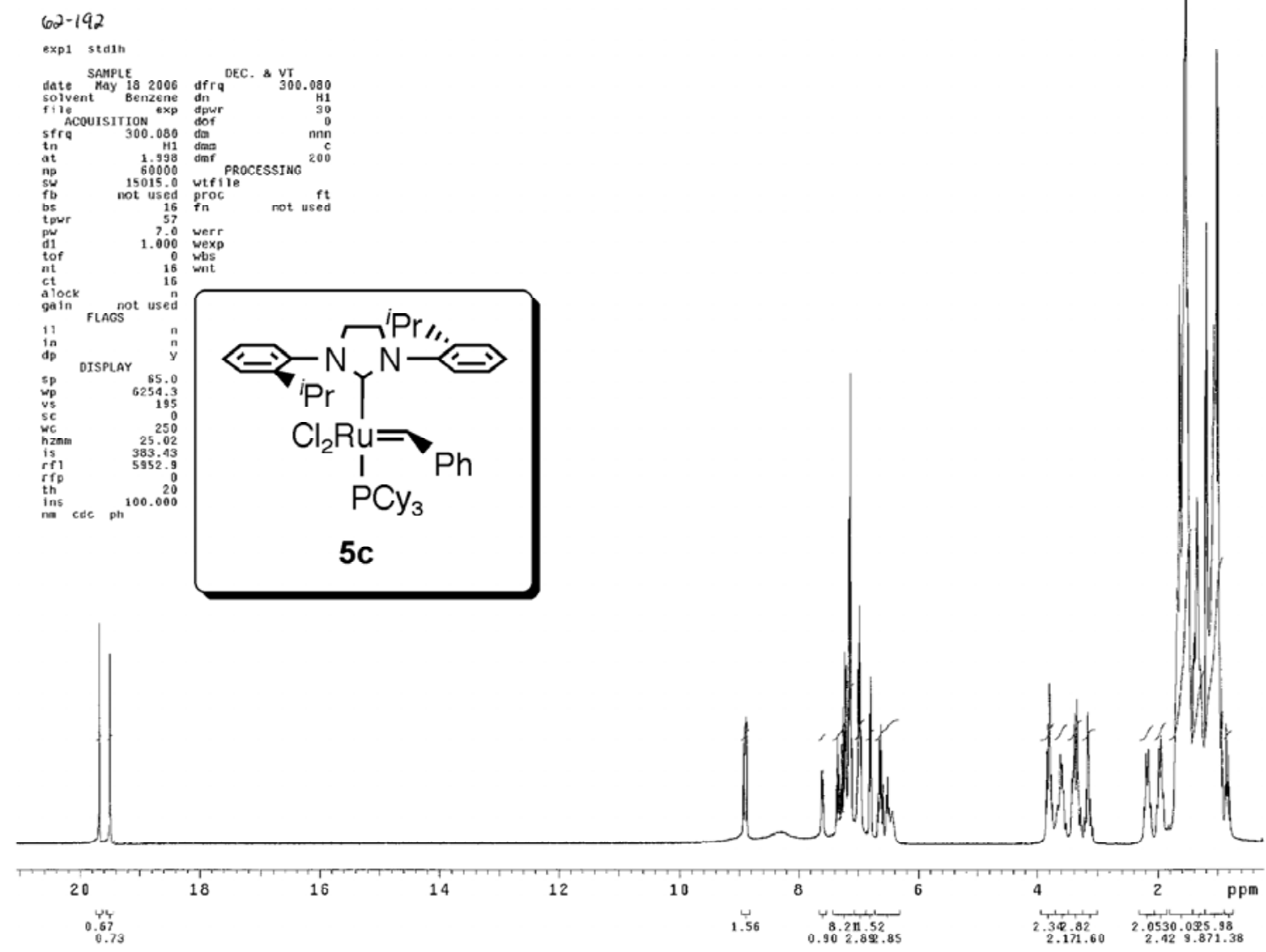


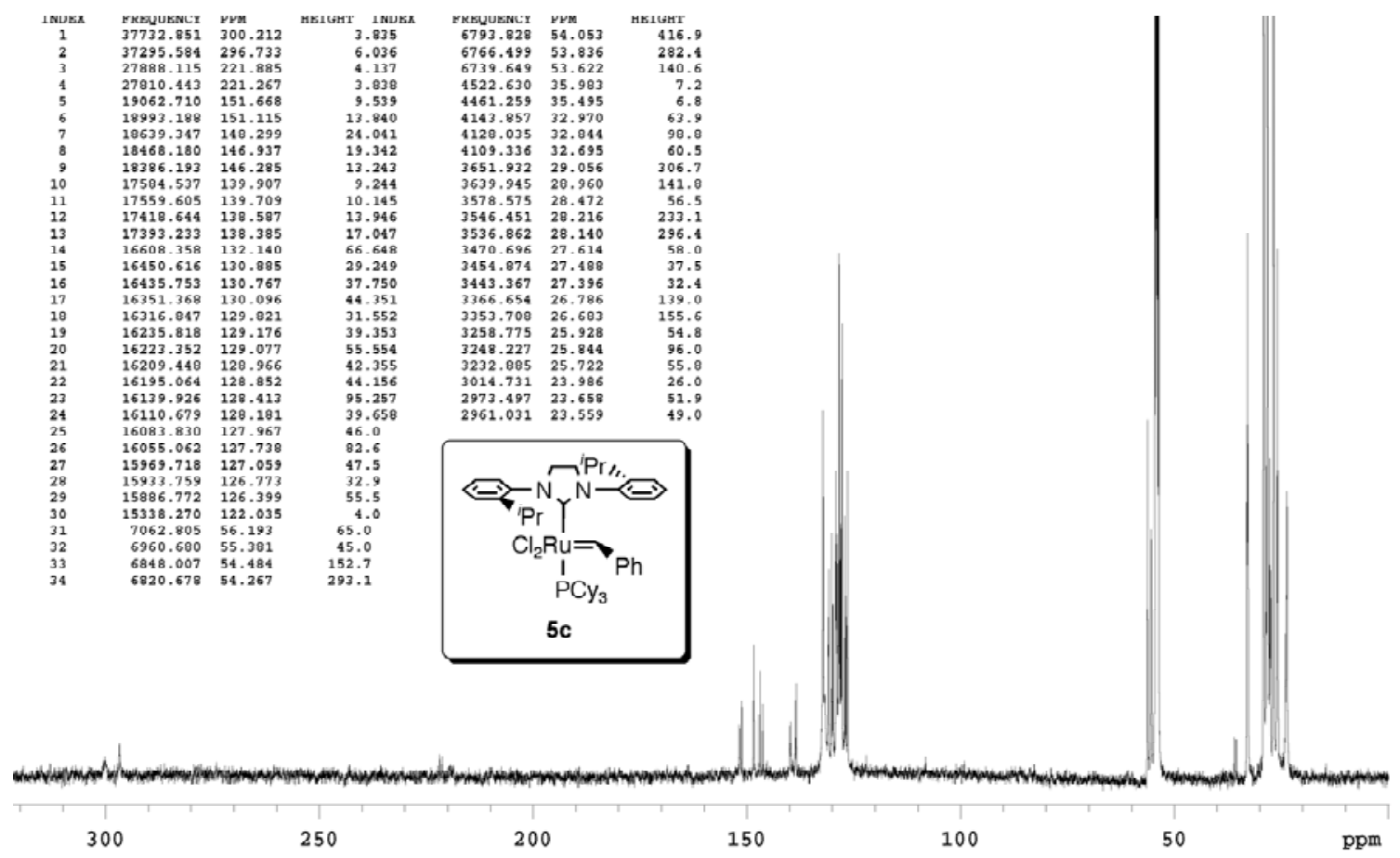




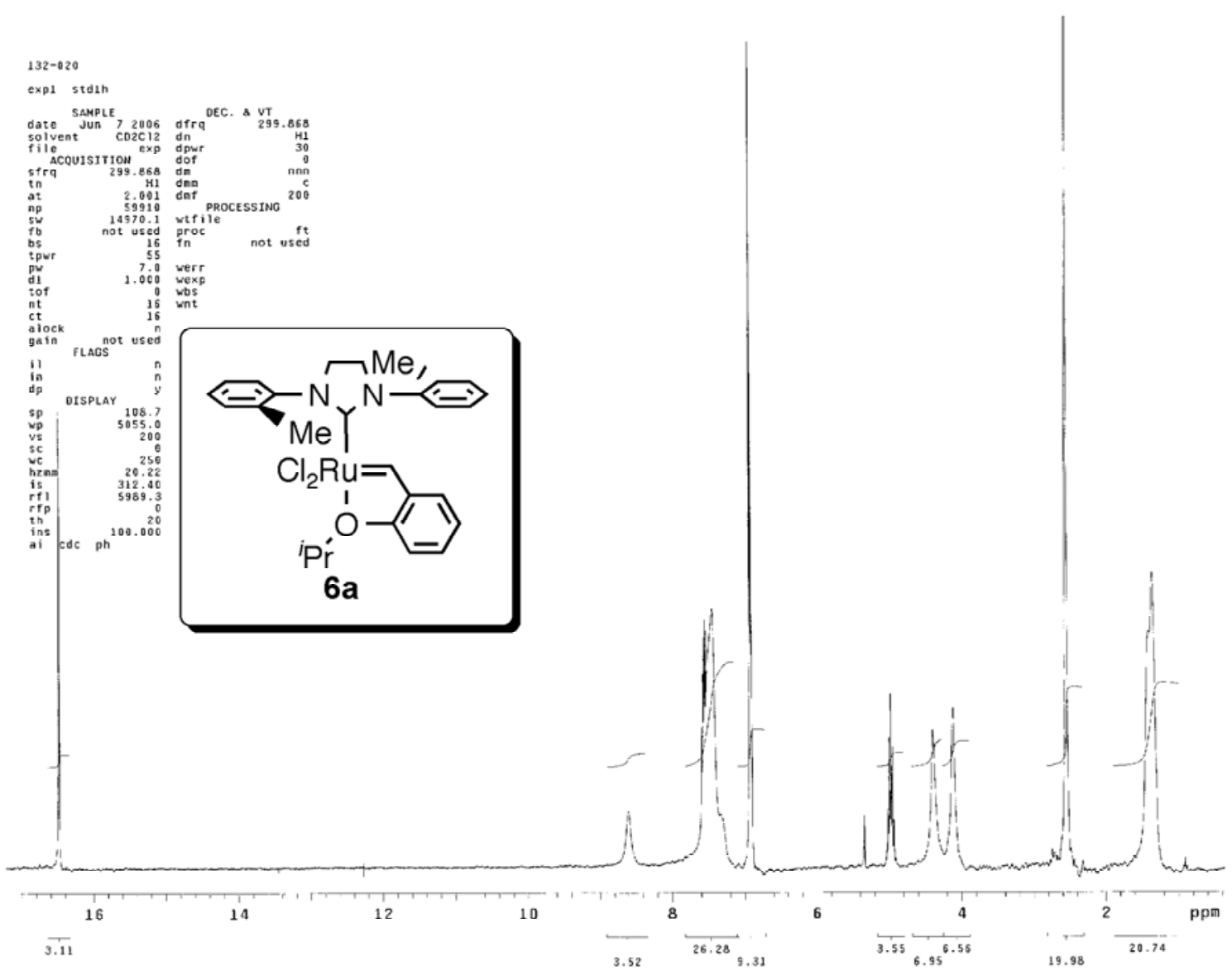




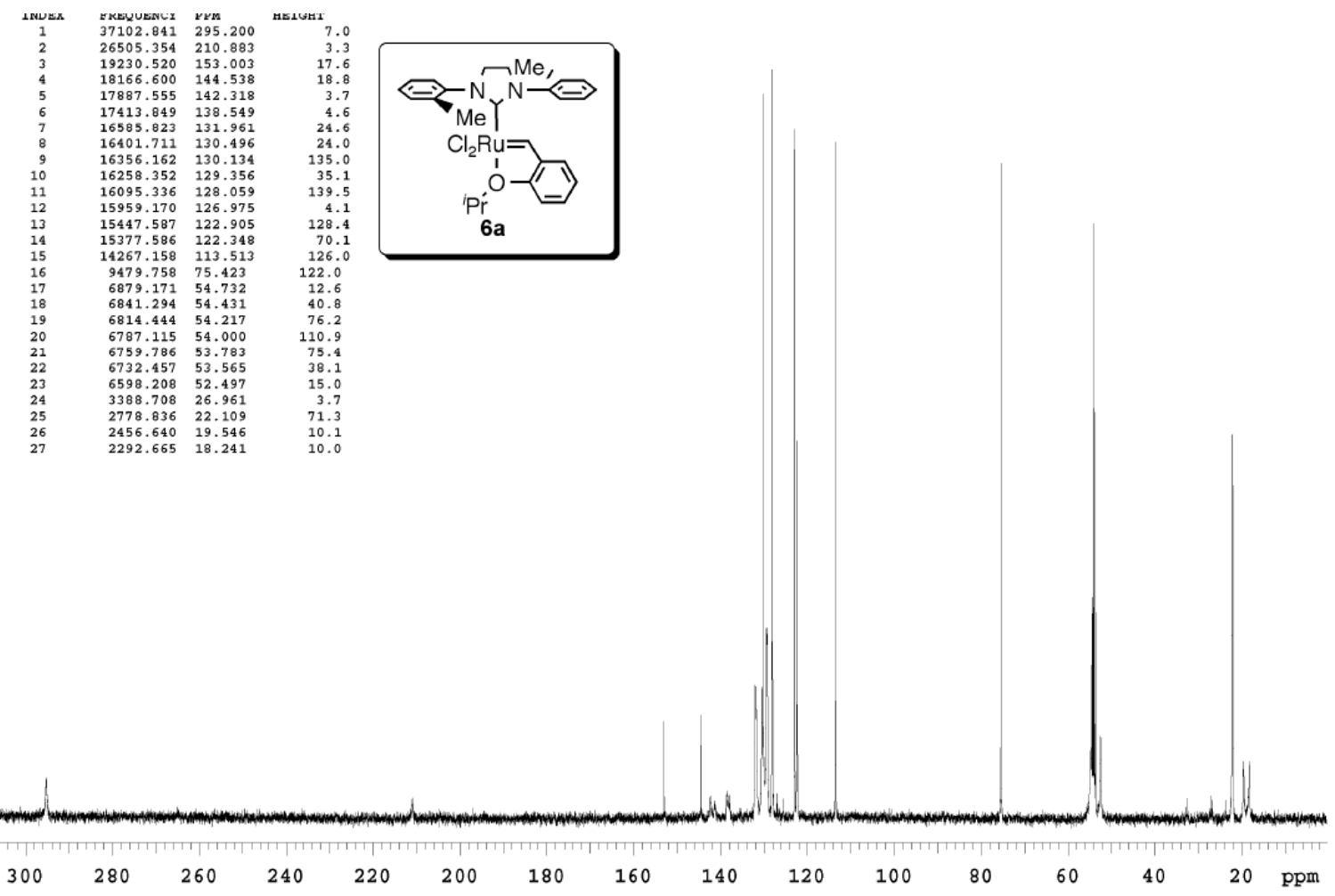




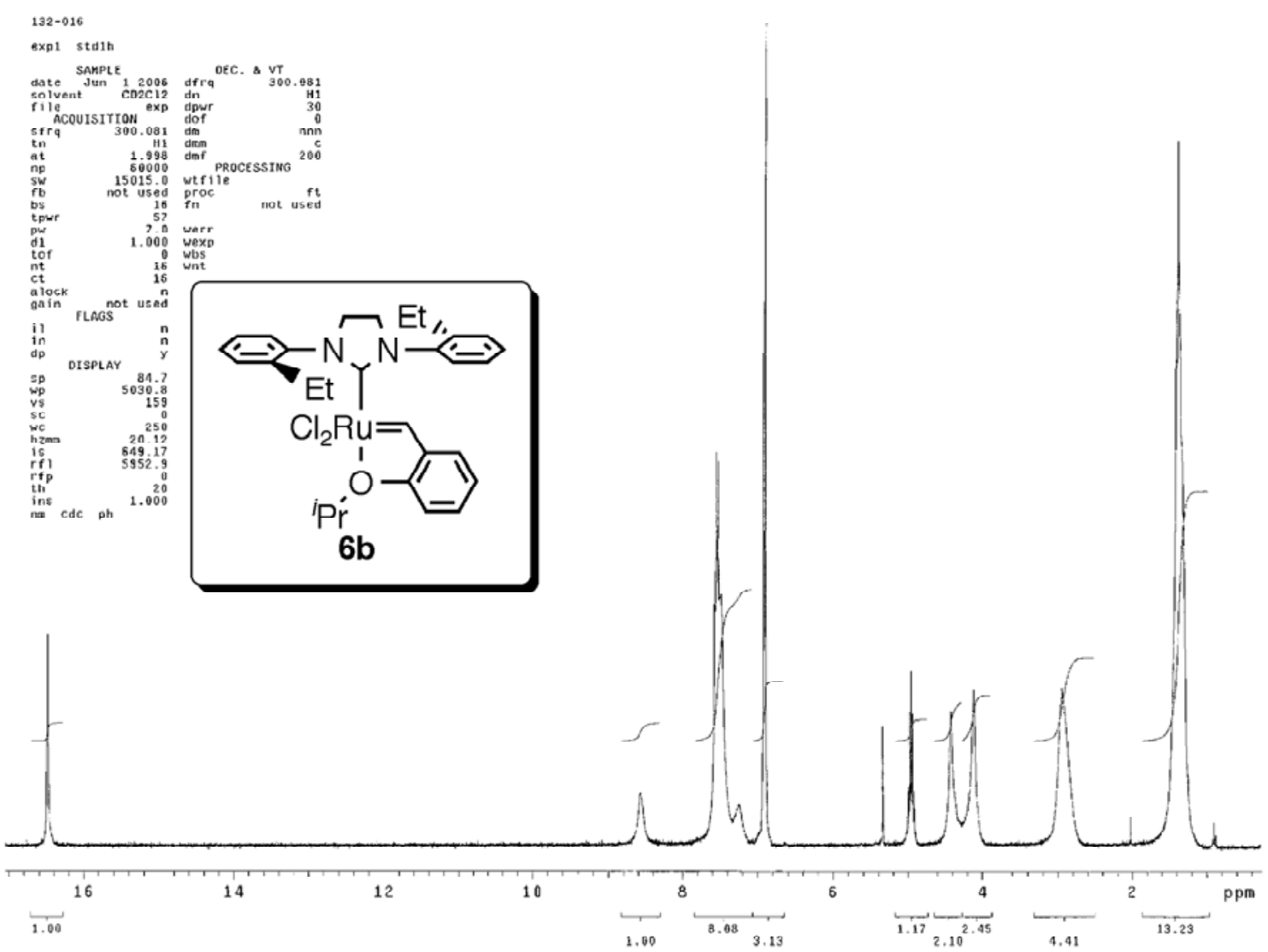




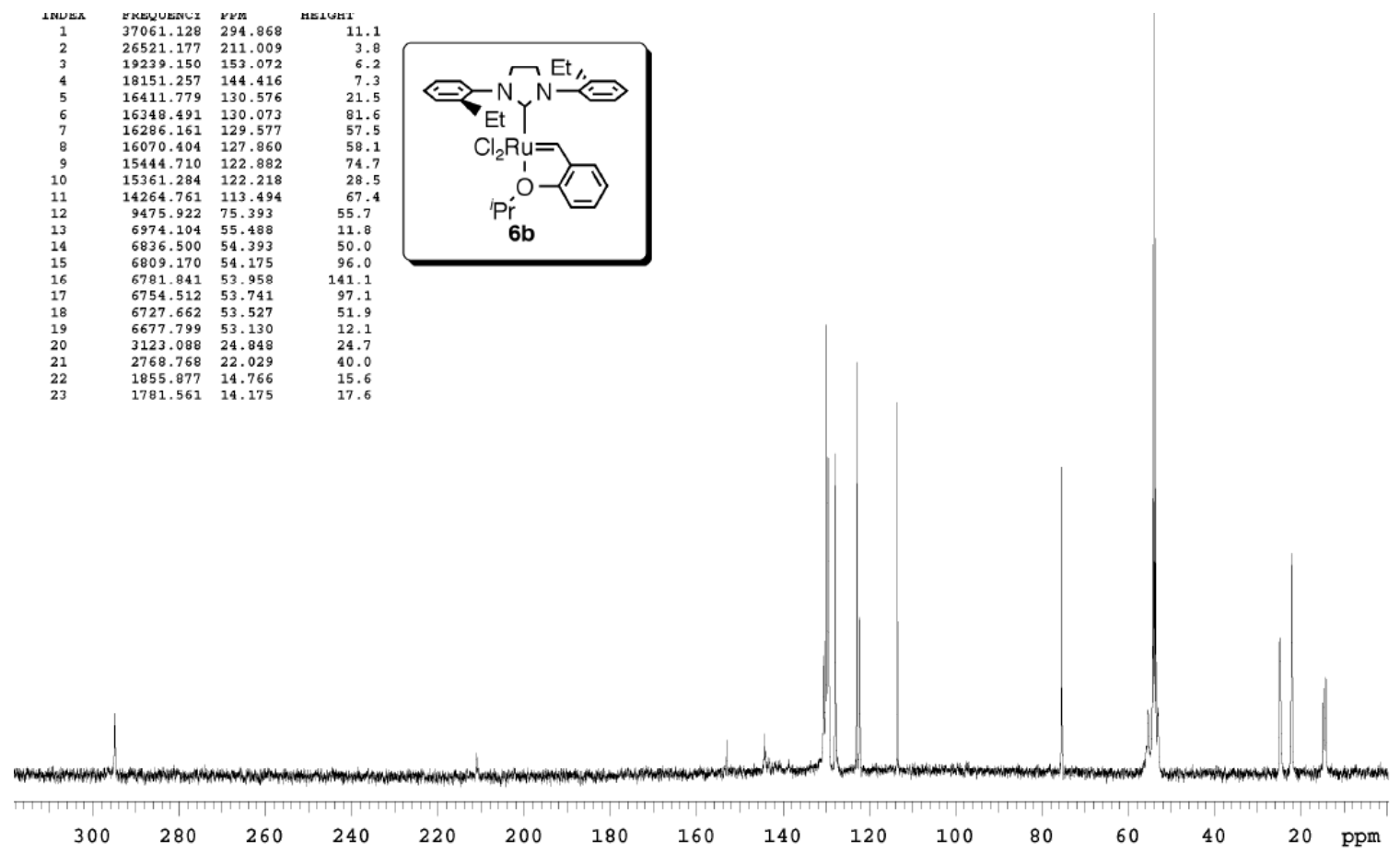




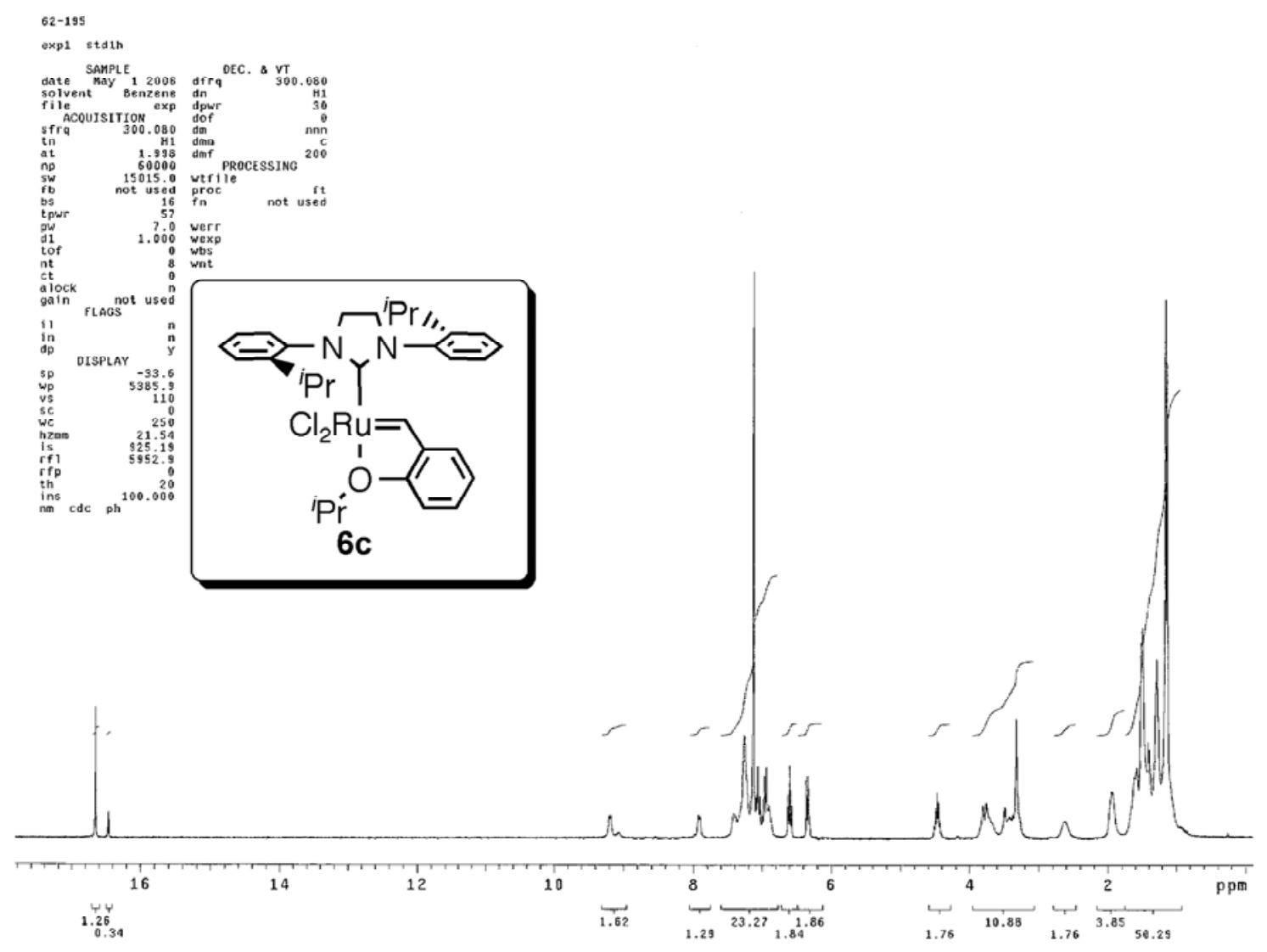




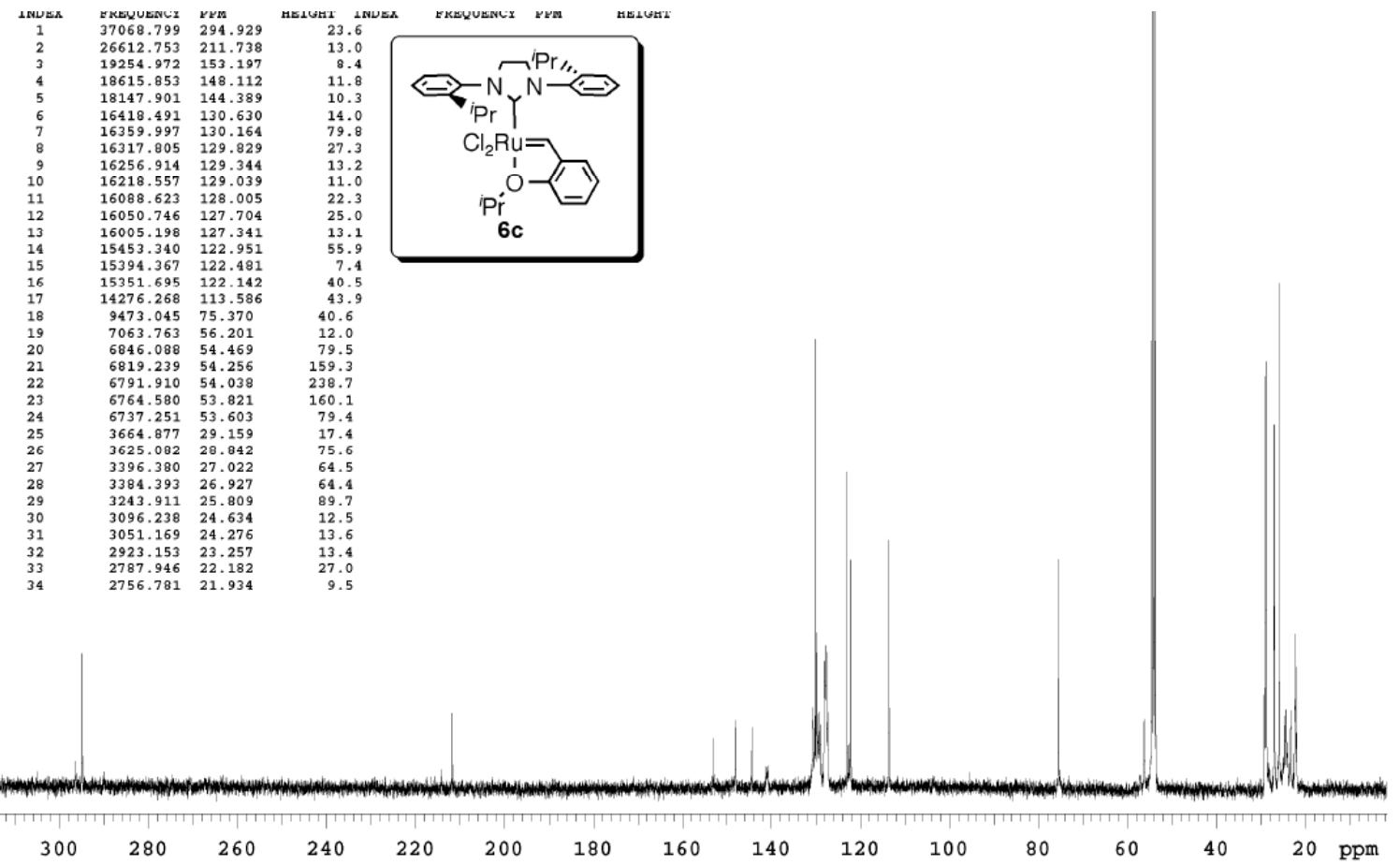




\section{REFERENCES}

${ }^{i}$ Schwab, P.; Grubbs, R. H.; Ziller, J. W. J. Am. Chem. Soc. 1996, 118, 100-110.

${ }^{\text {ii }}$ For complete details, see: Ritter, T.; Hejl, A.; Wenzel, A. G.; Funk, T. W.; Grubbs, R. H. Organometallics 2006, 25, 5740-5745.

iii For syntheses of the substrates and isolation procedures for S6-S9, see: Berlin, J. M.; Campbell, K.; Ritter, T.; Funk, T. W.; Chlenov, A.; Grubbs, R. H. Org. Lett. In Press.

${ }^{\text {iv }}$ Crystallographic data have been deposited at the CCDC, 12 Union Road, Cambridge CB2 1EZ, UK and copies can be obtained on request, free of charge, by quoting the publication citation and the deposition number 635259 . 